\title{
Social Activity in Gothenburg's Intermediate City: Mapping Third Places through Social Media Data
}

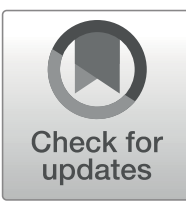

\author{
Marco Adelfio $^{1} \cdot$ Leticia Serrano-Estrada $^{2}$ • Pablo Martí-Ciriquián ${ }^{2}$. \\ Jaan-Henrik Kain ${ }^{1} \cdot$ Jenny Stenberg ${ }^{1}$
}

Received: 13 November 2019 / Accepted: 4 March 2020/

Published online: 27 March 2020

(C) The Author(s) 2020

\begin{abstract}
This research focuses on the intermediate city, composed of urban areas located right outside the city center typically maintaining an in-between urban/suburban character. It aims to explore the degree to which this segment of the city exhibits urban activity and social life through the identification of activity areas in the so-called Third Places. Four intermediate city neighborhoods in Gothenburg, Sweden are adopted as case areas and are analyzed using a twofold approach. First, socio-economic statistics provide a quantitative understanding of the case areas and, second, geolocated Social Media Data (SMD) from Foursquare, Google Places and Twitter makes it possible to identify the intermediate city's urban activity areas and socially preferred urban spaces. The findings suggest that a) the four analyzed intermediate city areas of Gothenburg all have a degree of social activity, especially where economic activities are clustered together; b) Third Places in more affluent areas tend to be linked to commodified consumption of urban space while neighborhoods with lower income levels and higher ethnic diversity seem to emphasize open public space as Third Places; and c) nowadays the typology of Third Places has evolved from the types identified in previous decades to include additional types of places, such as those you pass on the way to something else (e.g. gas and bus stations). The study has verified the value of SMD for studies of urban social life but also identified a number of topics for further research. Additional sources of SMD should be identified to secure a just representation of Third Places across diverse social groups. Furthermore, new methods for effective cross validation of SMD with other types of data are crucial, including e.g. statistics, on-site observations and surveys/interviews, not least to identify Third Places that are not frequently present (or are misrepresented) in SMD.
\end{abstract}

Keywords Social media $\cdot$ Third places $\cdot$ Intermediate city $\cdot$ Gothenburg

Marco Adelfio

adelfio@chalmers.se

Extended author information available on the last page of the article 


\section{Introduction, Key Facts and Research Questions}

The compact city has emerged in both research and policy as an ideal urban model to face the increasing urbanization and its subsequent pressures on cities. Even if there are critical voices (Neuman 2005), compact cities are expected to be resource efficient, liveable, lively and equitable (Boyko and Cooper 2011; UN-HABITAT 2012). Thus, they are acknowledged as "the preferred response to the goal of sustainable development" (Hofstad 2012: 2). Being key compact city benefits (Saaty 2013; Rani and Mardiah 2015), social interaction, social activity and social vitality should be given special attention. The City of Gothenburg has clearly acknowledged the strategic social benefits of compactness in its currently undergoing process of densification. According to the policy document Development Strategy Gothenburg 2035, high density "gives a city life that is attractive and creates a feeling of security" (City of Gothenburg 2014: 6).

By contrast, suburban development is commonly associated with "anti-urban" (Stevenson 2003: 126) semantics and, unlike the compact city, is seen to create "roadblocks" to sustainable development (Hanlon 2015: 133). Accordingly, "the 'stereotypical' suburb" is expected to produce "a lack of social diversity and sense of community together with an unsustainable way of living" (Adelfio 2016). Between these two extreme positions lies the "intermediate city", which is "the part of the city just outside the city centre" (City of Gothenburg 2014: $3)$. Due to their in-between character, such intermediate areas are expected to incorporate certain compact city/urban properties, including the presence of activity and social life, but whether this is actually the case is still an underexplored issue. In order to tackle this knowledge gap, the paper aims to explore the degree of activity and social life in Gothenburg's intermediate city, focusing on four local case areas - Hammarkullen, Kålltorp, Skår and Flatås -. Particular attention is given to the presence of the so-called Third Places (Oldenburg 1989), representing spaces for social meeting and interaction. The analysis will be conducted through the use of descriptive statistics combined with Social Media Data (SMD) to address the following research questions:

1. Q1. What urban activities and meeting places exist in the intermediate city of Gothenburg as identified through SMD?

2. Q2. Is it possible, based on SMD, to identify some of these meeting places as Third Places in Gothenburg's intermediate city?

The structure of the paper is as follows. First, a literature review is provided, delving into two main topics: i) the intermediate city as a concept that refers to the specific segment of the urban area being the focus of this study; and ii) the potential that SMD offer for analysing urban phenomena and, in particular, for identifying Third Places in urban areas. The method is subsequently explained, succeeded by a description of the case areas. Finally, the results are presented followed by a discussion of these and the main conclusions reached. 


\section{Literature Review}

\section{The Intermediate City: Bridging the Gap between the City as "theater of social activity" vs. the Lifeless Periphery}

Both research and policy identify the compact city as an ideal urban development pattern for sustainable development (UN Habitat 2012). In the academic literature the concept is widely established (Jenks, Burton \& Williams 1996; Churchman 1999; Dieleman and Wegener 2004; Boyko and Cooper 2011; Westerink et al. 2013) and generally considered as something positive (Moliní and Salgado 2012) although a unique definition is still missing (Churchman 1999; Burton 2002; Neuman 2005; Kain et al. 2016). Even though the term was firstly used in the 1970s by Dantzig and Saaty (1973), the role of the compact city centre as catalyst for economic activity and social vitality was highlighted also in earlier research. As stated by Ye several "classical urban ecologists such as Mumford, Wirth, Burgess and Jacobs promote the compact city as the crucial site for urban life" (Ye 2008:28). In particular, in 1937 Lewis Mumford advocated for the role of cities as "theater of social activity" (Mumford 1937:94) while, some decades later, Jacobs declared that thriving city centres are "natural generators of diversity and prolific incubators of new enterprises and ideas of all kinds" (Jacobs 1961:145). More recently, Rani and Mardiah have stated that "residents of compact urban form tend to have higher chance to have social interaction with their neighbours" (2015: 822).

Worldwide, compact city policies have been promoted by international organizations, highlighting their benefits for the citizens, as they "can positively enhance the life of the city dweller" (UN-Habitat 2012: 81) improving social cohesion and wealth while simultaneously tackling suburban sprawl (EU Ministers 2007). Also, urban compactness is seen to improve urban economy since "the richer, the denser" (World Bank 2009: 56) and lead to green growth objectives (UN-Habitat 2012).

In contrast, suburbia has a "negative connotation" (Adelfio 2016: no page) as focus of unsustainable sprawl (EEA-FOEN 2016). This has led to the emergence of a "suburban question" (Kirby and Modarres 2010: 114) arguing "whether postwar suburbs are environmentally and socially sustainable, whether they are fountains or deserts of social capital and social cohesion" (Walks 2013: 1472).

Swaying between these extreme positions, previous research has touched on "the existence of a kind of a hybrid urban model (between the hyper-sprawled cities and compact cities)" (Díaz-Pacheco and García-Palomares 2014: 2). Location plays a twofold role in the definition of such an "intermediate city" (City of Gothenburg 2014: 3), located just outside the inner city. At the local level, the term refers to the position of urban areas between the urban centres and the outwards suburban settlements. The hybrid character between city and suburbia has led to the use of the term "in-between city" (Keil and Young 2009: 488) in Canada, deriving from Sieverts (2003). Notwithstanding, even if it lies between the urban and the suburban, the "inbetween city" concept refers to an area "which is neither city nor landscape" (Sieverts 2003: 3), therefore certainly less urban than the aforementioned intermediate city. Still, the Zwischenstadt concept provides "a conceptual alternative to the hegemonic discourse that focuses on the traditional city as an unquestioned planning ideal" (Vicenzotti and Qviström 2018: 124). In Sweden, this hegemony has caused a 
privileged attention of planners towards the inner areas of the cities (Vicenzotti and Qviström 2018; Bergman 2008). Furthermore, the intermediate city also partially overlaps with the definitions of "inner suburbs" (Bollens 1988; Jackson 1985; National Association of Home Builders (NAHB) 2002; Orfield 1997), "inner ring suburbs" (Downs 1981; Drier 1996) and "first tier suburbs" (Hudnut 2003).

At the global scale, the geographical location of the intermediate city makes a difference in terms of characterization. While "in the US inner suburbs are suffering from the spread of inner city problems" (Greater London Authority - GLA 2002: 27), in Europe these areas have a more positive characterization. For instance, "in France the suburb has always been seen as second best compared to the centre" while in London it "retains much of its appeal and the threat comes from the revival rather than the further decline of the inner city" (Greater London Authority - GLA 2002: 27). Distinguishing the contextualized characteristics and values of the intermediate city is key to overcoming the risk of an over-generalized (Healey 2011), institutionalized (Górgolas 2018) and universalized idea of the compact city, connected to an obsessive identification of old European city centres as those exclusively incarnating the compact city ideal (Vicenzotti and Qviström 2018). While usually "the ideal of the 'European city' is presented as a densely developed urban area with a focus on quality public transport and a more balanced social structure" (Lawton and Punch 2014: 864), this paper shifts the attention from the European city cores to their surrounding areas, recognizing their value as foci of social activity.

\section{The Potential of Geolocated Social Media Data for Urban Analysis}

The relevance of urban studies based on SMD is supported by recent statistics. The number of social media and online services users has experienced an exponential increase in recent years. During the period from 2006 to 2016, Internet use has grown by $485 \%$ in Europe (Miniwatts Marketing Group 2016). Specifically, the penetration percentage of Internet for the Swedish population was over 93\% in 2018 (SCB 2019) with an expected continued future growth in both Internet and virtual social networks use.

Given this context, recent research on urban life has increasingly involved the interpretation of data retrieved from social networks (Fu et al. 2017). Previous work using such data sources has addressed a diversity of urban-related issues. Among them, attention has been given to the identification of points and places of interest for users (Huang et al. 2015; Van Canneyt et al. 2012), smell and sound perception (Aiello et al. 2016; Martínez et al. 2014; Quercia et al. 2015), infrastructure planning (Morandi et al. 2014), and the analysis of tourism consumption and mobility (Cerrone 2015; Mcardle et al. 2014).

For such a research, social networks represent a valuable source of information since, despite the fact that not the whole population uses these communication platforms, they provide a representative sample of citizens' preferences, opinions and urban activities (Martí et al. 2017, 2019). Moreover, geolocated data offers a wide range of opportunities for studying, monitoring and interpreting the behaviour of urban dwellers, their activities, preferences and movement patterns, both as individuals and in terms of their social interaction. The analytical value of such information is twofold. On the one hand, researchers have broadly used SMD to identify the quantity and types of urban activities as well as their characteristics (Agryzkov et al. 2016a, 2016b; Fu et al. 2017; García-Palomares et al. 2018; Salas-Olmedo et al. 2018; Steiger et al. 2015). On the 
other hand, such data has been applied to infer and interpret intangible phenomena occurring in the city, such as emotions, social preferences or the detection of sociability spaces (Agryzkov et al. 2016a, 2016b; Cerrone 2015; Frank et al. 2013). These two research approaches complement each other when conducting complex analysis of urban reality.

\section{Exploring Social Activity through Third Places: Concept and Research Application}

Oldenburg's concept of Third Places (Oldenburg 1989, 2001) refers to urban spaces that promote meetings and encourage social life and community building. Recognizing Third Places in today's urban setting is key to identifying informal and preferred gathering places and, most importantly, places that potentially can build a sense of community. In Gothenburg, Third Places are important for the bursting and vibrant social city life which has led it to be deemed "the world's most sociable city" in a recent survey (Coldwell 2017: no page).

The contemporary study of Third Places can be grouped according to three lines of research. The first group studies physical Third Places as those places that encourage community encounters (Oldenburg et al. 1999:10; Oldenburg and Brissett 1982: 270). These are spaces that foster socialization and communication outside an individual's first and second places of daily life, namely home and work (Jeffres et al. 2009; Mehta and Bosson 2010; Oldenburg and Brissett 1982).

In the second group, scholars suggest that online websites and social networks nowadays play the role of virtual Third Places (Mcarthur and White 2016; Memarovic et al. 2014; Steinkuehler and Williams 2006). The "contemporary Third Places" (Memarovic et al. 2014) allow individuals to feel companionship by remotely socializing and being part of a virtual community. These studies argue that, as in the case of physical Third Places, social networks and other online socially-driven communication platforms possess the same attributes, such as a levelling nature (Jeffres et al. 2009). For instance, Third Places are neutral, inclusive, accessible and playful (Oldenburg et al. 1999). These are characteristics that also e.g. Facebook has, albeit in the virtual field, given that anybody can have an account and freely search and interact with other users.

In the third group, scholars point out that socialization in physical spaces can be encouraged by online interaction. This is possible via online games or other social activities convened via social networks that act as computer-supported ice-breakers among strangers, resulting in physical spaces becoming Third Places from time to time (Rogers and Brignull 2002; Yoon et al. 2004). Another example is people organizing social gatherings among like-minded individuals, resulting in a "digital enthusiasm" (Gerbaudo 2016) that culminates in spikes of people engaging both online and offline, as often occurs in political demonstrations, such as in the Spanish 15-M Indignados movement of 2011.

Previous research has used more traditional methods - such as field-work observation - for identifying Third Places in a community (Jeffres et al. 2009; Mehta and Bosson 2010), typically adopting a mix of quantitative and qualitative methods. For instance, Memarovic et al. (2014) rely on field studies to observe local social activity 
"hubs" and consider them as Third Places. Jeffres (2009: 337) conducts interviews asking individuals which spaces they considered as "places where people might chat informally or where friends and neighbors might go for a conversation". Mehta (2010) follows a similar approach but adds more granularity to the identification of Third Places. He explores general categories of places and differentiates those that have or have not been considered as Third Places by interviewees. For instance, certain coffee places and shops may or may not have the physical and perceptual "ingredients" to be considered Third Places as they may not substantially support social behaviour (Oldenburg and Brissett 1982: 270). Physical characteristics that render a place suitable for social gathering are e.g. those analysed by Mehta (2010), which include personalization, permeability, seating and shelter. Still, apart from specific physical characteristics, the identification of Third Places also requires a consideration of their nature as essentially common places where ordinary but well integrated activities occur:

"The dominant activity [that takes place in the Third Place] is not 'special' in the eyes of its inhabitants, it is a taken-for-granted part of their social existence. It is not a place out-siders find necessarily interesting or notable Not even to its inhabitants is the third place a particularly intriguing or exciting locale. It is simply there, providing opportunities for experiences and relationships that are otherwise unavailable" (Oldenburg and Brissett 1982: 270).

Even though the more recent literature has recognised that social networks are an important component of physical Third Places (Memarovic et al. 2014), to the authors' knowledge, there is no research that has demonstrated the usefulness of online data for the identification of Third Places. This paper takes the stance that, if Third Places are taken-for-granted by individuals, almost as a subconscious part of their urban existence (Oldenburg and Brissett 1982: 270), it may be difficult to identify these through traditional field-work interviews. In view of this, the hypothesis set for this study is that Location-Based Social Networks (LBSNs) can uncover oblivious Third Places through the virtual traces of people's presence. For instance, people virtually checking in and posting a comment or an idea about an urban space generates Volunteered Geographic Information (VGI) (Goodchild 2007) about their interests, preferences and behaviours (Campagna 2016a, 2016b; Quercia et al. 2015) which would otherwise be difficult to recognise.

\section{Contextualization}

\section{Four Case Areas within Gothenburg's "Intermediate City"}

The Development Strategy of the City of Gothenburg highlights the importance of the "intermediate city" for the future development of the city, i.e. those parts of the city located just outside the city centre (City of Gothenburg 2014, see areas marked with orange in Fig. 1). Currently, these areas are characterized by a quite low density and an apparent lack of a vibrant social life. The city plans to densify the intermediate city by adding a total of 45,000-55,000 homes during 20 years. The overall idea of the strategy is to turn the city more liveable by increasing the proximity to different types of 
services, amenities and meeting places. In addition to densifying and diversifying this intermediate city, the strategy emphasizes that "local squares and other meeting-places can be renovated and supplemented to improve their attractiveness" (2014: 8). Some of these meeting places seem obvious, such as shops, cafés and local squares, while there is a lack of data regarding most of them (if they exist).

The four case areas - Hammarkullen, Kålltorp, Skår and Flatås - are all situated in the intermediate city (see Fig. 1). They have been chosen with regard to a variation in terms of building types (see Fig. 2) and demographics but they also have certain similarities. Hammarkullen is predominantly a working-class area, now with a large immigrant population and some socioeconomic challenges. It was built during the late 1960s and the 1970s to respond to urgent housing needs in the city. Hammarkullen has an apparent open modernist plan and is predominantly car free, with roads encircling the area. The greenery is generous and the buildings are sparsely placed in the landscape, including large-scale housing blocks, lower apartment buildings, row houses and villas. Kålltorp was developed as a relatively

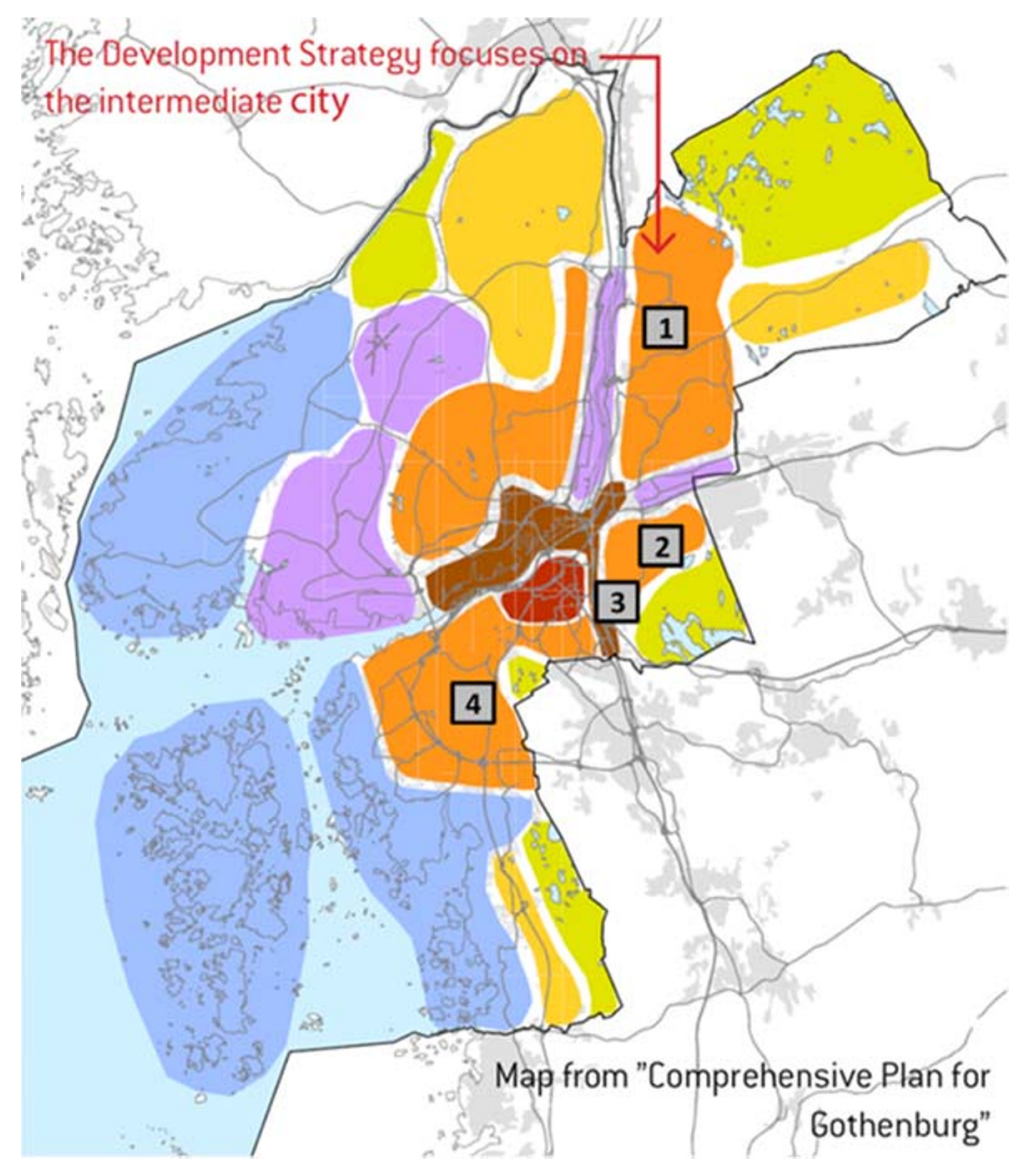

Fig. 1 Gothenburg's development strategy drawing on the city's comprehensive plan, with the intermediate city marked orange (source: Base map from city of Gothenburg 2014). The case areas are indicated by the authors as 1) Hammarkullen, 2) Kålltorp, 3) Skår and 4) Flatås 

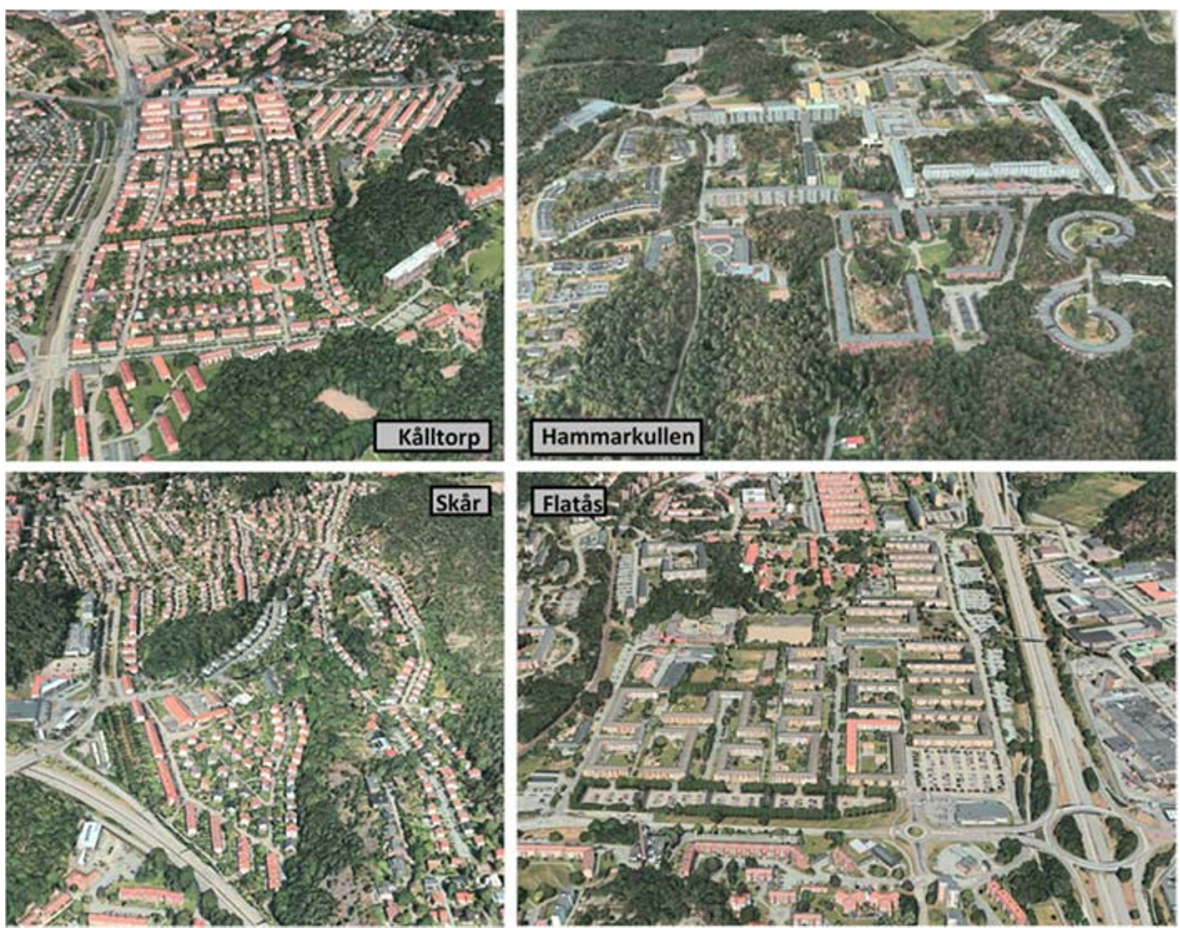

Fig. 2 Aerial photos of the four case areas. Map data from apple maps@

small-scale working-class area in the 1920s and 1930s based on a well elaborated planning document inspired by Camillo Sitte's planning ideal, just before Swedish planning shifted towards modernism (Sundborg 2001). The area is now turning into a middle-class neighbourhood. It has a mix of single-family housing, semi-detached houses, and two and three storey apartment buildings. Skår was developed as a middle-class area just after Kålltorp in the 1930s and 1940s. The plan was laid out by the same architect as Kålltorp but gradually became more influenced by modernism. The plan still retains many qualities of the previous era and the building stock is small scale with single family villas, semi-detached houses, and small two storey apartment buildings. It is now an upper-middle class area. Flatås was built as a working-class area in 1962-1964. The area is mainly characterized by large three to four storey apartment blocks. In comparison with the contemporary Hammarkullen, Flatås has a less open plan and is instead layed out as a city block structure, where the housing blocks enclose large open yards. Again, in comparison with Hammarkullen, Flatås has become a stable housing area with less socioeconomic challenges and is now more of a middle-class area.

\section{Method}

The present study focuses specifically on the activities and behaviour of users reflected in various SMD. These data are interpreted and used as superimposed layers of 
complementary information to that of statistics to pinpoint areas of social activity and Third Places. The research adopts a dual approach by using SMD to identify urban activities and sociable spaces via the analysis of citizen preferences. The research is mainly quantitative relying on two main sources of information: the use of basic statistics for descriptive purposes, and the use of SMD for the identification of Third Places and to assess urban activity of four case areas in Gothenburg.

\section{Descriptive Statistics}

Statistics (see Table 1) were used to describe the socio-economic profile of the case areas. This includes demographic data, density values, motorization rate, average personal income and diversity of countries of origin. There is a twofold rationale for adopting these specific statistics. On the one hand, these basic statistics contribute to positioning the areas in the intermediate city between the urban and the suburban, e.g. higher density and social mix can be considered as properties of urban cores while a high car dependency is typical of suburbia. On the other hand, statistics can be connected to the use of social media, as well as to social life and Third Places. For example, later in the article, the population and the average income are compared with the amount of digital data generated by social media in each case area.

The demographic data for each case area include population, as number of inhabitants and households and as the density of inhabitants per hectare. Density is also expressed in terms of dwellings per hectare. Data for both population and dwelling density refer to the statistical boundaries of primärområden (primary areas) officially determined by the public administration in Gothenburg (statistik.goteborg.se). As Gothenburg is a sparsely built city, the case areas include a remarkable presence of unbuilt areas. Hence, a complementary calculation of density is obtained by focusing on a more realistic perimeter for density - i.e. a $20 \mathrm{~m}$ buffer taken from the buildings of the case areas - in this way excluding the large unbuilt spaces from the calculation (drawing on Berghauser Pont and Haupt 2009).

Table 1 Descriptive statistics data

\begin{tabular}{|c|c|}
\hline Data & Data source \\
\hline $\begin{array}{l}\text { Population and households } \\
\text { (2017) }\end{array}$ & City of Gothenburg (http://statistikdatabas.goteborg.se) \\
\hline Inhabitants per Ha. (2017) & City of Gothenburg (http://statistikdatabas.goteborg.se, calculation by author \\
\hline Dwellings per Ha. (2017) & City of Gothenburg (http://statistikdatabas.goteborg.se, calculation by author \\
\hline $\begin{array}{l}\text { Motorization rate (cars/1000 } \\
\text { inhab. 2017) }\end{array}$ & City of Gothenburg (http://statistikdatabas.goteborg.se, calculation by author \\
\hline $\begin{array}{l}\text { Average personal income } \\
\quad(2016)\end{array}$ & City of Gothenburg (http://statistikdatabas.goteborg.se) \\
\hline $\begin{array}{l}\text { Diversity of countries of } \\
\text { origins }\end{array}$ & $\begin{array}{l}\text { Tenants Association (calculated by authors as average entropy index of } \\
\text { sub-areas included within each of the case areas) }\end{array}$ \\
\hline
\end{tabular}


The motorization rate is included to obtain a comparison in terms of car dependency in the case areas. High car ownership and dependency have been associated in the literature with negative impacts on social relationships and community (Duany et al. 2000) and also with individualistic cultures (Dingil et al. 2019). Hence, it becomes relevant for a study on meeting places and social activity.

The last two indicators, average personal income and diversity of countries of origin are useful to explore if there is a connection between level of wealth and social mix. The latter is calculated using an entropy index extracted from a study developed by the Swedish Union of Tenants about diversity and segregation in Sweden (https://kartor. hyresgastforeningen.se). Such an index ranges from 0 to 1, "identifying spatial units that are completely homogenous" when the value is equal to 0 "or maximally diversified which means that all population groups are equal in size" (Apparicio et al. 2014: 3 ) if the value is equal to 1 .

\section{Sources and Methodological Use of Social Media Data}

The following method was applied for using geolocated social networks to identify today's relevant Third Places and to assess urban activity in the selected case areas.

\section{Data Collection and Sources}

Three geolocated social networks were used as the information sources. Geolocated data from Foursquare, Twitter and Google Places were retrieved for the case-study areas using a web application developed for that purpose- the Social Media Urban Analyser (SMUA) (Martí et al. 2019). This application accesses the following information held by the social networks through their Application Programming Interface (API):

i. A list of registered venues was obtained from Foursquare, a check-in based geolocated social network;

ii. A list of economic activities within the case areas was retrieved from Google Places, a web service linked to the Google Maps Platform, that includes information about establishments, geographic locations and main points of interest (Google Developers 2019); and

iii. A list of geolocated tweets that were generated from the predefined spatiotemporal limits was obtained from Twitter, a micro-blogging social network where users share texts of 280 characters maximum length.

All three listings were retrieved in a .cvs file format. The date of retrieval was 29 May 2018 for Foursquare and Google Places and Twitter data were listened to from 24 May 2018 to 25 December 2018.

The retrieved social networks data include a large quantity of metadata variables. However, for this research only certain types of data have been used (see Table 2).

The three selected social networks possess specific characteristics that render them useful for this research. In the case of Google Places and Foursquare, these characteristics are: 
Table 2 Social networks data variables used for this study

\begin{tabular}{|c|c|c|c|}
\hline General variables & Foursquare & Twitter & Google places \\
\hline \multirow[t]{2}{*}{ 1. Location } & Longitude & Longitude & Longitude \\
\hline & Latitude & Latitude & Latitude \\
\hline $\begin{array}{l}\text { 2. Temporal } \\
\text { information }\end{array}$ & Cumulative data on venues & $\begin{array}{l}\text { Time the tweet was } \\
\text { posted }\end{array}$ & Updated data on registered places \\
\hline \multirow{5}{*}{$\begin{array}{l}\text { 3. User generated } \\
\text { data }\end{array}$} & Venue name & Tweet text & Place name \\
\hline & Venue address & - & Place address (vicinity) \\
\hline & Check-ins & - & Average place ranking \\
\hline & Visits & - & - \\
\hline & Users & - & - \\
\hline $\begin{array}{l}\text { 4. Data } \\
\text { categorization }\end{array}$ & $\begin{array}{l}\text { Hierarchy of categories and } \\
\text { sub-categories }\end{array}$ & - & $\begin{array}{l}\text { Categories, sub-categories, } \\
\text { sub-sub-categories }\end{array}$ \\
\hline 5. Data ID & Venue ID and URL & Tweet ID & Place ID \\
\hline
\end{tabular}

i. Functionality. Foursquare has been designed to fulfil a social purpose. It works as a community building platform where users must be signed in to be able to check in a venue and broadcast their presence. For Google Places, anybody with a Google account can rate or review a registered establishment or place.

ii. Registration method of places and venues. In Google Places a place can be registered automatically by Google, whereas in the case of Foursquare, the venues are mostly registered by users. Thus, if a place or establishment is registered in both Foursquare and Google Places (see Fig. 10), it can be inferred, with some degree of certainty, that the place has more social relevance than other listings that are only registered in a single source.

iii. Data categorisation. As shown in Table 2, Foursquare venues and Google Places are grouped into categories and sub-categories that are descriptors of the particular type of activity. This characteristic allows different degrees of granularity in the analysis.

iv. Locative and tracking properties. Google tracks user location and encourages users to recommend or rate a place. Foursquare also passively tracks user whereabouts irrespective of them checking-in to the venue, recording the number of users, visits and check-ins that have taken place in a given venue.

Indeed, Foursquare data serves in this research as a people-counting method, allowing for both a qualitative and quantitative approach to the information. The check-in value represents the total amount of check-ins; the number of users is the total number of unique Foursquare users that ever checked in a venue; and the number of visits is the total number of times users have been in a venue, regardless of whether they have checked in or have just passed by the venue (Foursquare Inc. 2018). For example, in the case of a Foursquare venue with one user that has visited 20 times but has only checked in once, the venue would have received one user, 20 visits and one check-in.

Twitter data is used to characterise the spatiotemporal presence of people in the case areas, specifically this study will be focused on the tweet activity in urban areas 
distinguishing between both weekdays and weekends. This source is used as an additional layer of information to support the recognition of Third Places, taking the assumption that tweet location and concentration patterns suggest, to a degree, which urban areas have more or less people presence.

Based on the previous considerations and cited literature (Martí et al. 2019; SerranoEstrada et al. 2016; Van Weerdenburg et al. 2019), this study considers Google Places places as the urban activity "on offer", that is, a listing that includes all the economic activities in a neighbourhood; Foursquare venues as urban activities "on demand", that is, listings containing the urban spaces and establishments that have received, at least, one user check-in for broadcasting her/his presence in the space; and, the geolocated tweets, as indicative of people presence in a given urban area.

\section{Location Based Social Networks data pre-processing and analysis}

Following retrieval, data was manually pre-processed prior to analysis. This represents an important step for reducing possible bias related to data duplication and, in general, ensuring a degree of data representativity in terms of SMD reflecting actual physical activities. Specifically, verifying that places and venues are indeed physical urban spaces is a key task. Furthermore, it must be noted that this research acknowledges the fact that a sample of geotagged Tweets may not be representative of all Twitter users (Jiang et al. 2018: 13) but only of those who have deliberately chosen to share their geo-location. Moreover, other sources for biases need to be considered, such as the composition of social media populations. For instance, it is not possible to know the exact demographics of social media users in terms of gender, age, and political or religious orientation (Mayr and Weller 2017: 144). Lastly, issues linked to social media users' privacy (Buchel and Rasmussen Pennington 2017: 303) are also relevant for this study. For example, any type of information that relates to the users' identity was either not retrieved or was discarded.

\section{Data Pre-Processing}

Data pre-processing consisted mainly in the validation and the visualisation of data. The data validation was carried out to ensure that there was no data duplication and that each tweet, venue and place was in fact unique. For the most part, recognition of duplicates is a straightforward task for Foursquare and Google Places if the names and descriptions of venues and places as well as their geographic coordinates are unique. As for the Tweets, through a quick first visualization in a GIS program, overlapping tweets located on the same geographical location could be observed. Those showing irregular patterns and potentially compromising or skewing the results were revised and eliminated; for instance, tweets that had been being automatically generated and did not represent human activity.

\section{Data Analysis}

Once data were pre-processed, further data analysis consisted of five phases. 
I. The amount of LBSN data for each neighbourhood were analysed in relation to the demographic and economic characteristics. This included the spatiotemporal patterns of tweets from which a distinction was made between weekdays and weekends, and daytime (7:00-16:59) and evening (17:00-6:59) for shared tweets, considering Friday evening as part of the weekend.

II. The pre-processed data were visualized in a map for all neighbourhoods. In this study, Foursquare data served as a proxy of the visitation frequency in an urban area, similar to the "frequency of visitation" criteria adopted by previous field study researchers when interviewing participants to identify potential Third Places (Mehta and Bosson 2010: 10). Specifically, spatial concentration patterns of Foursquare venues were recognised, and data clusters were identified. Furthermore, Foursquare categories were ranked by their number of venues to identify which types of activities are more highly represented in each neighbourhood.

III. The spatial distribution and density of data, as well as the existence of datapoint clusters from different sources, were used as indicators of the degree of people presence and of urban liveability. Here, it was assumed that the lesser the concentration and the greater the dispersion of urban activities in a neighbourhood, the greater the likelihood of a decrease in opportunities for social interaction.

The main criterion used for the selection of potential Third Places was to recognise urban spaces or establishments included in both Google Places and Foursquare datasets. The reasoning behind this criterion is that, arguably, an urban space or establishment registered in both listings have a higher degree of social relevance. Places in Google Places are equivalent to all urban activities "on offer" whereas Foursquare venues are registered and checked-in by users themselves representing the spaces "on demand". Thus, Third Places were identified by closely examining the dataset listings and visualizations in order to pinpoint those places and venues located close together or with similar geographic coordinates and names. Subsequently, these places and venues were classified according to the Third Places categories suggested by Jeffres et al. (2009:338) (see Table 3). This classification has been selected mainly because the definition of a Third Place includes open public spaces and not strictly businesses, as in the case of the research from Mehta and Bosson (2010).

Venues and places that did not fall within any of the established categories were given a new category name. Arguably, these represent Oldenburg's taken-for granted Third Places (Oldenburg and Brissett 1982: 270), thus not explicitly but potentially being revealed by LBSNs.

IV. Once Third Places were recognised, Foursquare check-ins, visits and user numbers were analysed and considered as a proxy value for the number of "regulars" (Oldenburg 1989: 175) visiting a venue. These values provided clues on the difference between the types of Third Places among the four neighbourhoods at two levels: 1) at the category level, where the ranking of check-ins, users and visits enabled the identification of the most preferred and thus most frequented place types; and, 2) at the venue level, where the ranking of most checked-in venues allowed pinpointing specific spaces as most preferred Third Places. 
Table 3 Third Place types according to Jeffres et al. 2009:338

Third Places types (Jeffres et al. 2009)

$\begin{array}{llll}1 & \text { Bars and pubs } & 10 & \text { Recreation centers } \\ 2 & \text { Churches } & 11 & \text { Restaurants and cafes } \\ 3 & \text { Coffee shops } & 12 & \text { Schools, colleges, universities } \\ 4 & \text { Deli/local supermarket } & 13 & \text { Community centres, town meetings } \\ 5 & \text { Libraries } & 14 & \text { Clubs and organizations } \\ 6 & \text { Neighbourhood } & 15 & \text { Neighbourhood parties, block parties, cookous, barbecues } \\ 7 & \text { Neighbourhood inside, homes, } & 16 & \text { Senior centres } \\ & \text { apartments } & \text { Neighbourhood outdoors } & \\ & & 17 & \text { Media, online, newsletter, newspapers, phone, bulletin } \\ 9 & \text { Parks and outdoor recreation } & 18 & \text { Hair salons, barber and beauty shops } \\ 10 & \text { Recreation centres } & 19 & \text { Work }\end{array}$

V. Google Places places average rating value was analysed, providing a third-level approach to the data. The places average rating value and Foursquare venues check-ins, visits, and users were ranked. Here, Foursquare venue values permitted a more comprehensive picture of the type and significance of the social spaces in each of the neighbourhoods.

\section{Analysis and Results}

\section{General Attributes of the Case Areas}

It is useful to compare the population of the four case areas demographically, and these demographics will also be related below to the amount of data generated by social media.

While Kålltorp and Hammarkullen show similar absolute values of population in terms of number of inhabitants (8505 and 8204) they have very different household numbers (see Fig. 3). In contrast Skår and Flatås display more similar numbers of households (1747 and 1775) but not in terms of inhabitants.

When it comes to population density, the commonalities between the data also go in pairs. The most surprising similarity exist between Hammarkullen, a high-rise building suburb mostly inhabited by lower income inhabitants and Skår, an area dominated by single-family housing for the middle or upper class (see Figure 4, to the left). The percentage of the statistical areas of Hammarkullen and Skår occupied by buildings is also relatively similar, $4.1 \%$ for Hammarkullen and $6.6 \%$ for Skår. However, considering that the statistical areas in some cases include extensive unbuilt spaces, a comparison of the population density including only the $20 \mathrm{~m}$ buffer zone around the buildings shows that Hammarkullen has the highest density (118.96 persons per 


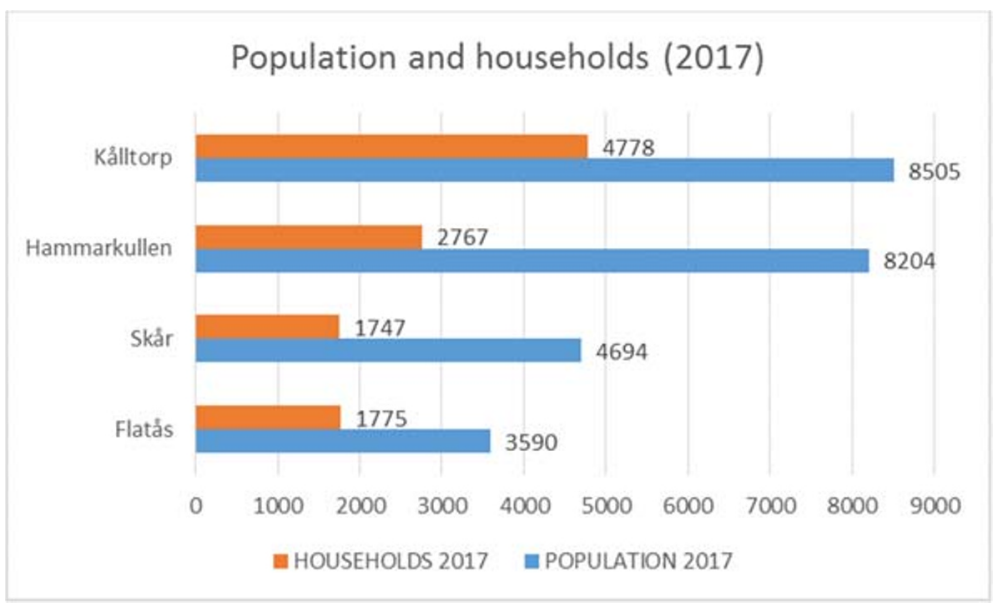

Fig. 3 Population and household numbers (2017) for the four case areas

hectare), followed by Kålltorp (90.70), Flatås (88.01) and Skår (52.94), giving a more realistic picture of the density inside the built-up areas of the neighbourhoods (see Fig. 4 , to the right). Also the density of dwellings changes significantly with the establishment of a $20 \mathrm{~m}$ buffer zone from the buildings (see Fig. 5), the most important change affecting the comparison between Hammarkullen ( 8.25 dwellings per hectare with the statistical boundaries and 42.78 dwellings with the $20 \mathrm{~m}$ buffer zone) and Skår (7.46 with the statistical area, similar to Hammarkullen, and 20.74 with the $20 \mathrm{~m}$ buffer zone, then half of Hammarkullen).

In terms of disposable family income, Skår is the richest area with around 1.5 times the Gothenburg value and 1.35 times the value of the city centre (see Fig. 6). Kålltorp almost reflects the average value of the whole city while the other two have a lower income level, Hammarkullen being the poorest area with around half the value of Gothenburg city.

There is not a direct linkage between income and use of cars, since Flatås is topping the ranking of the case areas for motorization rate, exceeding the value of the richer

\section{Population per Ha. (2017) \\ referred to statistical boundaries of case areas}

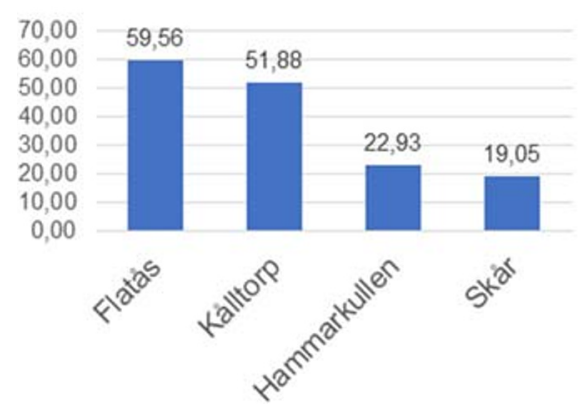

\section{Population per Ha. (20 m buffer)}

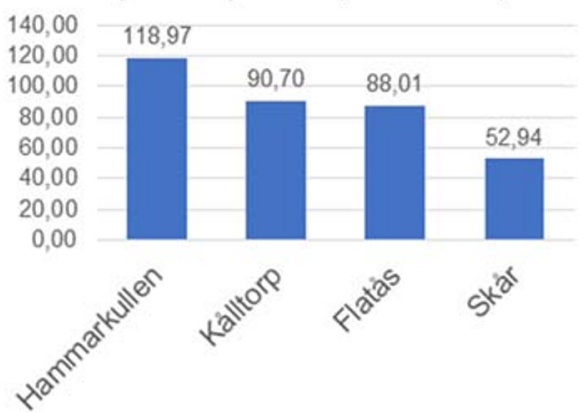

Fig. 4 Population density referred to the statistical boundaries (to the left) and with a $20 \mathrm{~m}$ buffer zone from the buildings (to the right) 
Dwellings per Ha. (2017)

referred to statistical boundaries

of the case areas

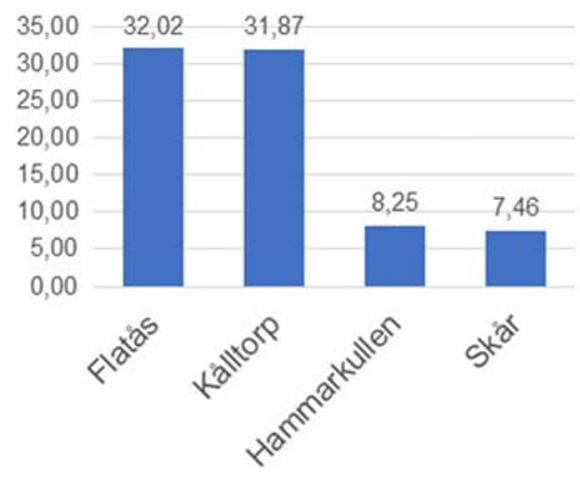

Dwellings per Ha. (20 m buffer)

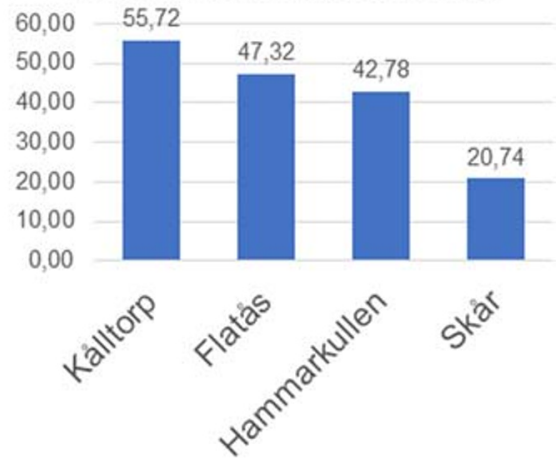

Fig. 5 Dwelling density referred to the statistical boundaries (to the left) and a $20 \mathrm{~m}$ buffer from the buildings (to the right)

Skår area (see Fig. 7). Hammarkullen is the area with the lowest use of cars (even lower than the city centre), the highest demographic density referred to the aforementioned $20 \mathrm{~m}$ buffer zone and the lowest income level, and is also the most diverse in terms of countries of origin (see Fig. 8). In contrast, the richest and less dense area, Skår, is the most homogenous/less diverse neighbourhood, with Kålltorp as a close second. Flatås ends up in between the two extremes, still above the city centre value. There is thus an inverse relation between social diversity measured in terms of countries of origin and income levels.

\section{Assessing Urban Activity and Third Places through Social Media Data}

\section{Demographic and Economic Statistics and the Presence of Social Media Data}

The total amount of LBSN datapoints obtained and analysed for each neighbourhood (Table 4) in relation to their demographic and economic characteristics offer some

\section{Average income per person in SEK (2016) Gothenburg value: 290800 SEK Gothenburg city centre: 317438 SEK}

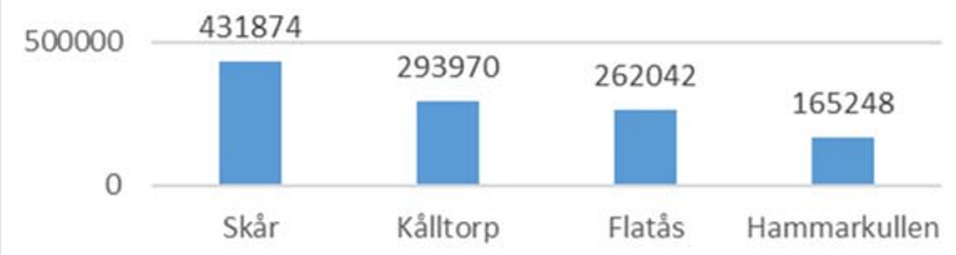

Fig. 6 Average income per person (2016) 


\section{Motorization rate (cars per 1000 inhabitants 2017)}

Gothenburg value: 285.77

Gothenburg city centre: 220.51

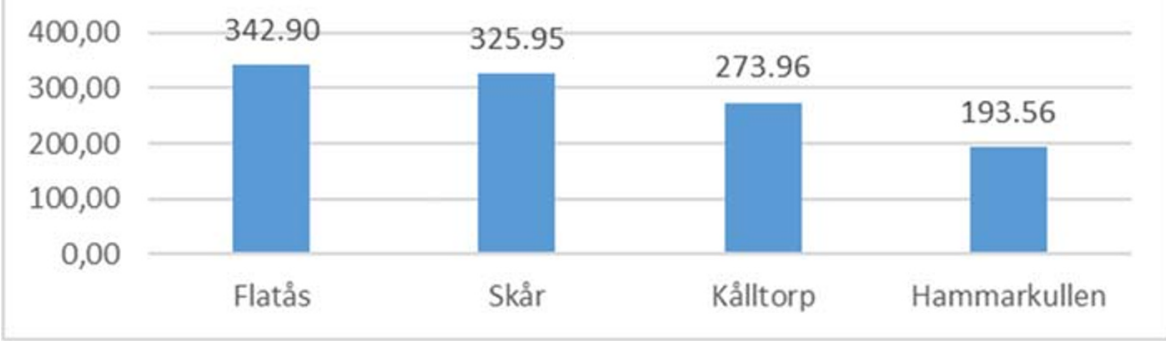

Fig. 7 Motorization rate (2017)

interesting results. The amount of LBSN data by population is not the same in all neighbourhoods (see Table 5). As can be observed, the ranking order of neighbourhoods in terms of the amount of Google Places datapoints shows that Kålltorp has the highest amount and Hammarkullen the lowest. As for Foursquare and Twitter there are some minor alterations in the ranking order, with Kålltorp having the most urban activity and Hammarkullen the least. These differences are likely due to the different urban character of each area since there is a correlation between the average income of the neighbourhood and the ratio of LBSN datapoints per 100 people, namely, the higher the average income for the neighbourhood, the higher the ratio of LBSN datapoints per 100 people. Significantly, the higher the average income, the greater the difference between the income figure and the number of LBSN datapoints per 100 people (see Table 5).

These differences have been calculated as follows for both variables (see Table 5): i. for each neighbourhood, the ratio of average income to the lowest average income (Hammarkullen); and ii. for each neighbourhood, the ratio of number of LBSN datapoints per 100 people to the lowest number of LBSN datapoints per 100 people (Hammarkullen). For example, Kålltorp's average annual income ratio is 1.78 times

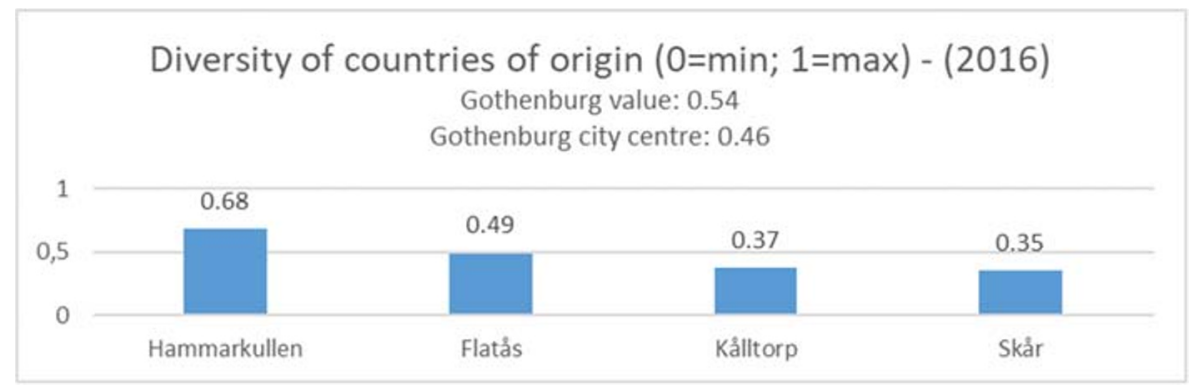

Fig. 8 Diversity of countries of origin (2016) with a value ranging from 0 to 1 
Table 4 LBSN datapoints per neighbourhood and social network

\begin{tabular}{|c|c|c|c|c|c|c|c|}
\hline \multirow[t]{2}{*}{ Neigbourhood } & \multicolumn{2}{|c|}{ Google places } & \multicolumn{2}{|l|}{ Foursquare } & \multicolumn{2}{|l|}{ Twitter } & \multirow{2}{*}{$\begin{array}{l}\text { Total } \\
\text { LBSN } \\
\text { datapoints }\end{array}$} \\
\hline & $\begin{array}{l}\text { Total } \\
\text { datapoints }\end{array}$ & $\begin{array}{l}\text { Datapoints } \\
\text { per } 100 \\
\text { people }\end{array}$ & $\begin{array}{l}\text { Total } \\
\text { datapoints }\end{array}$ & $\begin{array}{l}\text { Datapoints } \\
\text { per } 100 \\
\text { people }\end{array}$ & $\begin{array}{l}\text { Total } \\
\text { datapoints }\end{array}$ & $\begin{array}{l}\text { Datapoints } \\
\text { per } 100 \\
\text { people }\end{array}$ & \\
\hline Hammarkullen & 118 & 1.44 & 25 & 0.30 & 11 & 0.13 & 171 \\
\hline Flatås & 68 & 1.89 & 28 & 0.78 & 6 & 0.17 & 102 \\
\hline Kålltorp & 235 & 2.76 & 113 & 1.33 & 127 & 1.49 & 487 \\
\hline Skår & 237 & 5.05 & 62 & 1.32 & 18 & 0.38 & 319 \\
\hline
\end{tabular}

greater than Hammarkullen's and Kålltorp's LBSN datapoints per 100 people are 2.75 times greater than Hammarkullen's, whereas in the case of Skår, the neighbourhood with the highest average annual income, the comparative figures are 2.61 and 3.26, respectively.

Despite the fact that relatively less data was retrieved from Twitter (see Table 4), possibly due to the fact that only geolocated tweets were considered (i.e. tweets that have been sent from a GPS enabled device), the analysis of the total number, of the time and of the language of the tweet content allowed the recognition of variations among neighbourhoods (see Table 6). Kålltorp has the greatest Twitter activity of all neighbourhoods at all estimated timeframes as well as an important variety of languages: up to 12 different languages apart from Swedish and English. Flatås has the lowest Twitter activity followed by Skår, and their tweets are shared mostly in Swedish during the weekday evenings. Finally, the tweets in Hammarkullen suggest that there is more tweet activity in the weekday evenings.

\section{Spatial Concentration Patterns and Types of Urban Activity}

The geographical distribution of data (see Fig. 9) shows different concentration patterns of urban activities in each neighbourhood. In Kålltorp and Flatås clusters of activities are clearly identifiable. In Skår urban activity is concentrated in three clusters but in

Table 5 Comparing annual average income values to the number of LBSN datapoints per 100 people by neighbourhood

\begin{tabular}{lllllll}
\hline Neigbourhood & Population & $\begin{array}{l}\text { Annual } \\
\text { average } \\
\text { income } \\
\text { (SEK) } \\
\text { (a) }\end{array}$ & $\begin{array}{l}\text { Ratio of (a) to } \\
\text { the lowest (a) }\end{array}$ & $\begin{array}{l}\text { Total } \\
\text { LBSN } \\
\text { datapoints }\end{array}$ & $\begin{array}{l}\text { LBSN datapoints } \\
\text { per 100 people (b) }\end{array}$ & $\begin{array}{l}\text { Ratio of (b) to } \\
\text { the lowest (b) }\end{array}$ \\
\hline Hammarkullen & 8204 & 165,248 & 1.00 & 171 & 2.08 & 1.00 \\
Flatås & 3590 & 262,042 & 1.59 & 102 & 2.84 & 1.36 \\
Kålltorp & 8505 & 293,970 & 1.78 & 487 & 5.73 & 2.75 \\
Skår & 4694 & 431,874 & 2.61 & 319 & 6.80 & 3.26 \\
\hline
\end{tabular}


Table 6 Twitter data frequency per timeframe and language

\begin{tabular}{lllll}
\hline \multirow{2}{*}{ Timeframe } & \multicolumn{2}{l}{ Neighbourhoods } & & \\
\cline { 2 - 5 } & Hammarkullen & Flatås & Skår & Kålltorp \\
\hline Weekdays Morning (Friday INCL) 7:00-16:59 & 5 & 1 & 5 & 66 \\
Weekdays Evening (Friday EXCL) 17:00-6:59 & 16 & 2 & 9 & 25 \\
Weekends Morning (Friday EXCL) 7:00-16:59 & 5 & 1 & 3 & 33 \\
Weekends Evening (Friday INCL) 17:00-6:59 & 2 & 2 & 3 & 15 \\
TOTAL & 28 & 6 & 20 & 139 \\
Languages & & & & \\
Swedish (sv) & 26 & Flatås & Skår & Kålltorp \\
English (en) & 0 & 14 & 6 & 64 \\
Other languages & 2 & 4 & 0 & 63 \\
\hline
\end{tabular}

Hammarkullen most urban activities are clustered in a central location of the neighbourhood.

As for the Foursquare venues and their corresponding categories, different types of urban activity can be identified (see Table 7). The Foursquare category in Flatås and Skår with most checked in venues corresponds to "Professional and other places" whereas in Kålltorp and Hammarkullen the category ranked first is "Outdoors and recreation".

\section{Identification of Potential Third Places}

Identifying Third Places was possible by recognising which open public spaces and establishments were registered in both Foursquare and Google Places (see Figure 10). The listings in the datasets and the maps were both closely examined in order to identify coinciding attributes of venues and places, such as their location, geographical coordinates and names. Although this was a straightforward task for most cases, there were some few exceptions in which a) one space was registered twice in the same social network (such as Skatås in Kålltorp); and b) the geolocation of the dots representing venues and places differed for a few meters (see the red and yellow stars representing Folkhögskolan i Angered as a Third Place in Hammarkullen).

Subsequently, the identified Third Places were grouped into categories. In total, 19 Third Places categories were identified across all four case areas, of which 12 could be grouped within those defined by Jeffres et al. (2009) and 7 were given a new label (see Table 8). Furthermore, from the 19 identified Third Places categories, 13 correspond to indoor places, 4 represent outdoor open spaces and the remaining 2, which are related to transportation (Station and Gas station categories), are considered outdoor-indoor as the social activity potentially happens, depending on the case, e.g. at the check-out counter or the coffee place within a gas station building or at the fuel dispenser zone. 

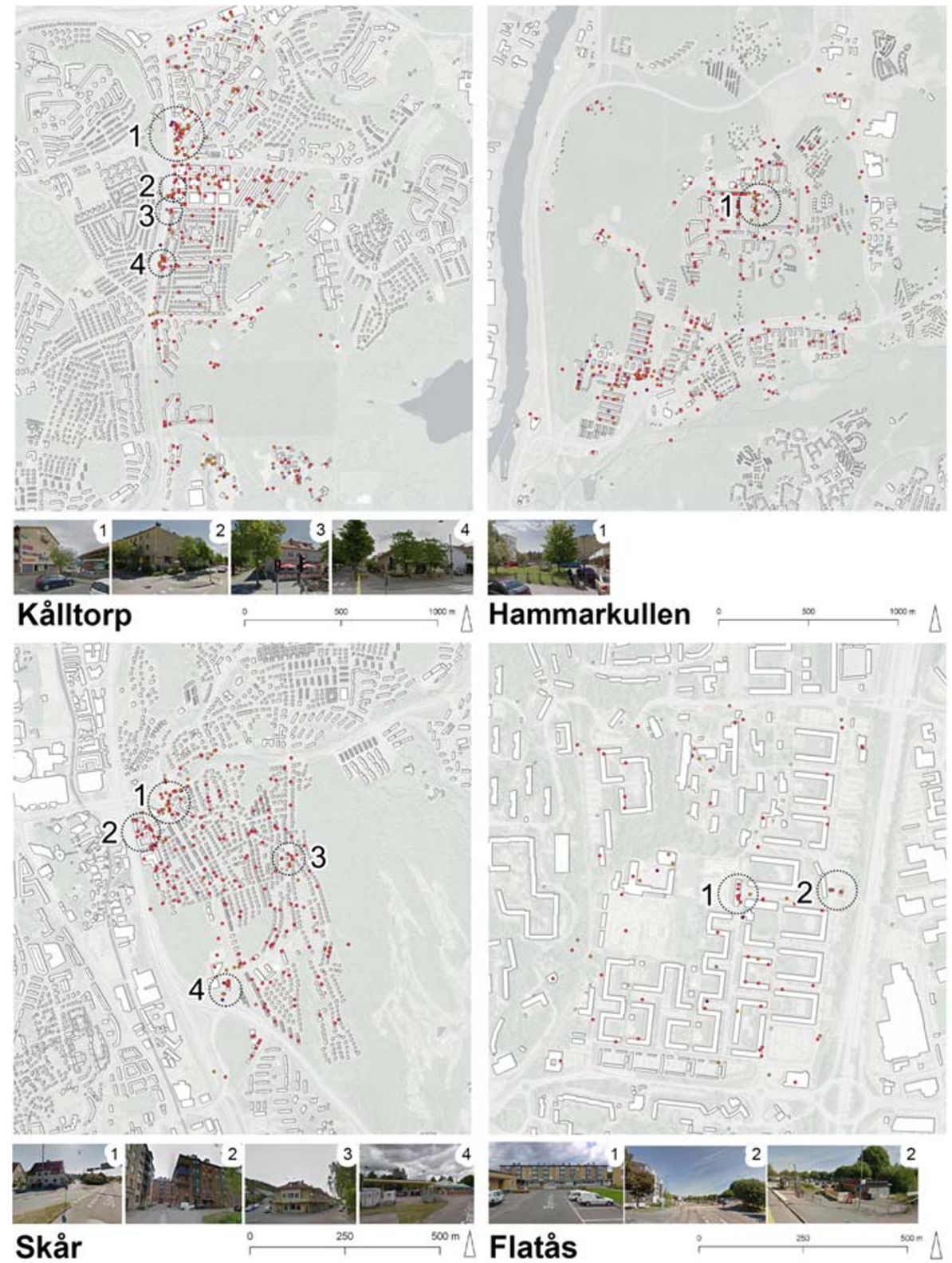

\section{Twitter}

$\triangle$ Weekdays Evenings (Fridays EXC)_17:00-6:59

- Foursquare

$\triangle$ Weekdays Morning (Fridays INC)_7:00-16:59

- Google Places

$\triangle$ Weekends Evenings (Fridays INC)_17:00-6:59

A Weekends Morning (Fridays EXC)_7:00-16:59

Fig. 9 Recognisable clusters of urban activity according to the social network data analysed. The photographs below show the urban character of these clusters. Base maps from Carto DB and open street maps. Photographs from Google street view 
Table 7 Ranking of foursquare venues per activity categories and their frequency distribution among the studied neighbourhoods

\begin{tabular}{llll}
\hline Category & Number of venues & Percentage & Checkins (total) \\
\hline Outdoors \& Recreation & 27 & $24 \%$ & 1693 \\
Shop \& Service & 23 & $20 \%$ & 1361 \\
Food & 20 & $18 \%$ & 789 \\
Professional \& Other Places & 12 & $11 \%$ & 227 \\
Undefined & 9 & $8 \%$ & 1983 \\
Travel \& Support & 8 & $7 \%$ & 1295 \\
Residence & 5 & $4 \%$ & 154 \\
College \& University & 4 & $4 \%$ & 43 \\
Arts \& Entertainment & 3 & $3 \%$ & 52 \\
Nightlife Spot & 2 & $2 \%$ & 198 \\
TOTAL & 113 & $100 \%$ & 7795
\end{tabular}

Skår

Professional \& Other Places

Shop \& Service

$16 \%$

Food

$13 \%$

192

Travel \& Support

$11 \%$

121

Undefined

$11 \%$

415

Outdoors \& Recreation

$10 \%$

182

Residence

$8 \%$

52

Nightlife Spot

$5 \%$

29

College \& University

Arts \& Entertainment

Hammarkullen

Outdoors \& Recreation

Professional \& Other Places

Travel \& Support

Undefined

Food

College \& University

Shop \& Service

Residence

$4 \%$

18

Arts \& Entertainment

$2 \%$

TOTAL

Flatås

Professional \& Other Places

Food 
Table 7 (continued)

\begin{tabular}{llll}
\hline Category & Number of venues & Percentage & Checkins (total) \\
\hline Outdoors \& Recreation & 4 & $14 \%$ & 81 \\
Shop \& Service & 3 & $11 \%$ & 130 \\
Residence & 2 & $7 \%$ & 64 \\
Nightlife Spot & 1 & $4 \%$ & 1 \\
TOTAL & 28 & $100 \%$ & 954 \\
\hline
\end{tabular}

The Third Places category types (see Fig. 11) found in both Foursquare and Google Places datasets were the most varied in Kålltorp (9 different categories), followed by Flatås (6), Skår (7) and Hammarkullen (5). However, in terms of the number of Third Places, the ranking is slightly different (see Table 9). Kålltorp remains the neighbourhood with most Third Places (15), Hammarkullen is second (10), Skår third (8) and Flatås last (7). As for the types of Third Places identified, less than $50 \%$ of them (see Table 9) are spaces that are typically considered to have an inherited degree of social character: Bars and pubs, churches, coffee shops, supermarkets and/or grocery stores, libraries, schools. However, the findings show that some Third Places in the case areas are either open spaces (parks and outdoor recreation, neighbourhood key residential open/gathering spaces) or other types of spaces (recreation centres, gas stations, etc). Nevertheless, analysing the ranking of venues by "frequency of visits" through the number of Foursquare visits, check-ins and users (see Fig. 11 and Table 9) Flatås' and Kåltorp's most visited Third Places are venues within the Deli/local supermarket category, but in both Kålltorp and Skår, also Gas stations have a degree of social gathering activities.

Even though most Third Places coincide in terms of their types in both Google Places and Foursquare, a distinction is worth making between the categories identified on each of the two social networks (see Table 9). The datapoints have been independently studied with focus on their rating values for Google Places places and on the number of check-ins, visits and users for Foursquare venues, providing four interesting findings related to the urban character of these Third Places:

i. Despite Hammarkullen being the neighbourhood with less social activity according to Foursquare Third Places, it is the only neighbourhood whose top three venues in terms of Foursquare checkins and visitors are represented by open public spaces. This type of socialization in open public spaces is likely to be beneficial to community building and the liveability of the urban spaces Fig. 12.

ii. In the case of Kålltorp’s Third Places, the recreation centre Kålltorps fritidsgård is the best rated in Google Places. However, it occupies the last position in the ranking of socially preferred spaces in Foursquare checkins, visitors and users. Instead, supermarkets and a gas station have more checkins, whereas Portens Bageri, a coffee shop, occupies the second last position on the ranking. 

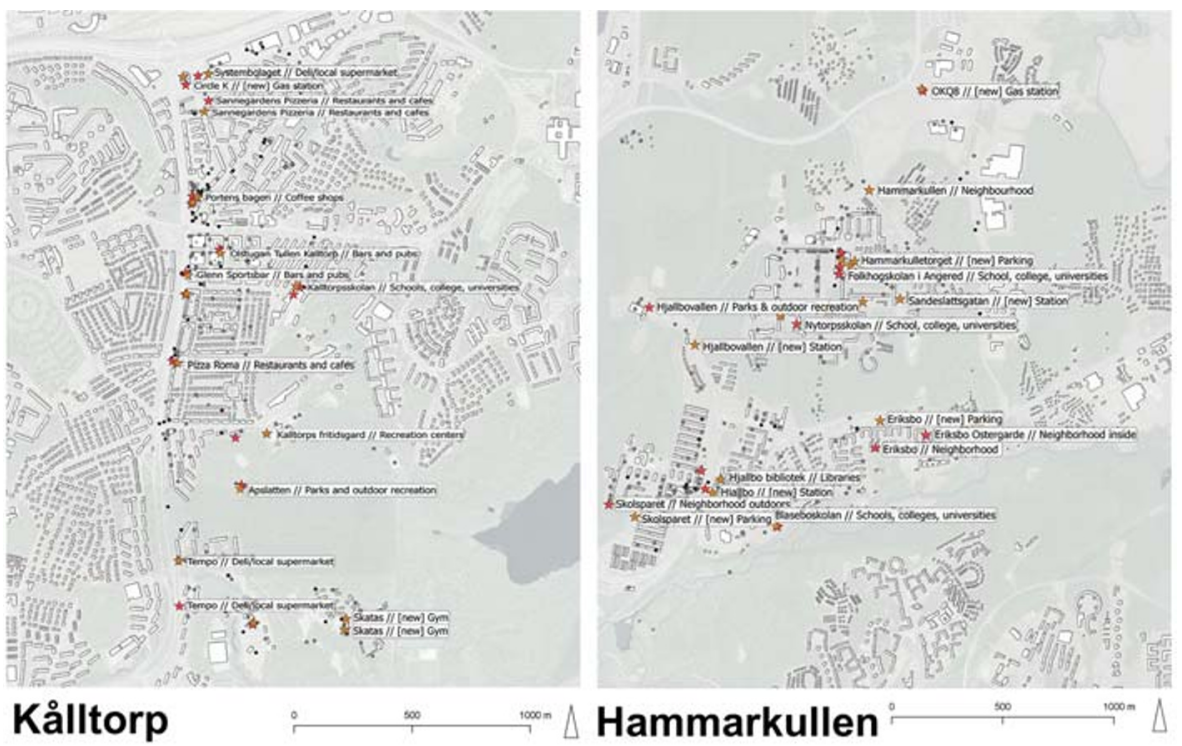

\section{Kålltorp}

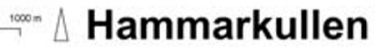

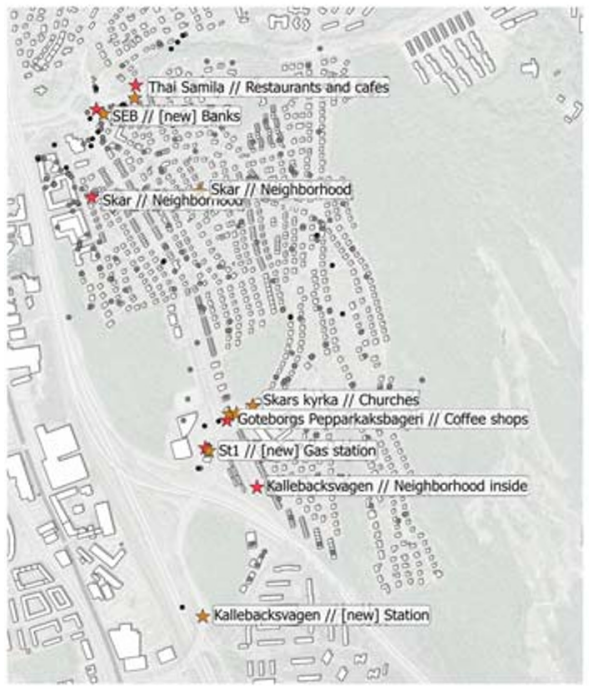

Skår

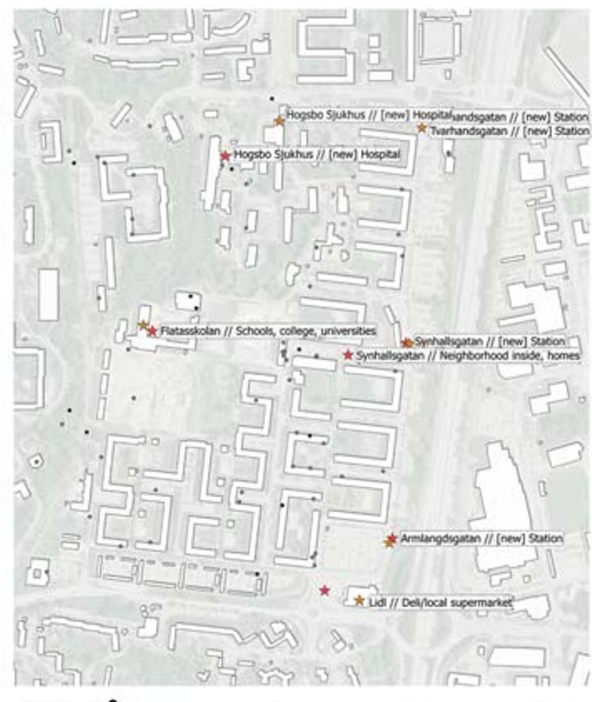

Flatås $\Delta$

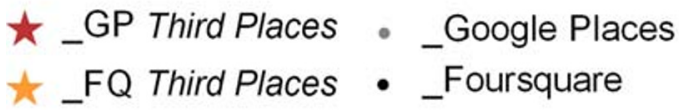

Fig. 10 Identification of Third Places. Base maps from Carto DB and open street maps

iii. A hospital and a bank are Third Places in Flatås and Skår, respectively, and occupy high positions in both Foursquare and Google Places rating lists.

iv. Findings suggest that in Hammarkullen and Skår there is a collective appreciation of the neighbourhood as an entity, as evidenced by the presence of related 
Table 8 Third Places categories obtained from the four case neighbourhoods

Third Places categories of the case neighbourhoods

\begin{tabular}{llll}
\hline 1 & Bars and pubs (indoor) & 11 & Restaurants and cafes (indoor) \\
2 & Churches (indoor) & 12 & Schools, colleges, universities (indoor) \\
3 & Coffee shops (indoor) & 13 & [new] Banks (indoor) \\
4 & Deli/local supermarket (indoor) & 14 & [new] Gas station (indoor/outdoor) \\
5 & Libraries (indoor) & 15 & [new] Gym (indoor) \\
6 & Neighbourhood (outdoor) & 16 & [new] Hospital (indoor) \\
7 & Neighbourhood inside, homes, apartments (indoor) & 17 & [new] Hotels (indoor) \\
8 & Neighbourhood outdoors (outdoor) & 18 & [new] Parking (outdoor) \\
9 & Parks and outdoor recreation (outdoor) & 19 & [new] Station (indoor/outdoor) \\
10 & Recreation centres (indoor) & & \\
\hline
\end{tabular}

categories in both social networks, i.e. Neighbourhood and Neighbourhood outdoors (see Table 9).

\section{Discussion and Conclusions}

This research proposes a method to identify locations of urban activity as Third Places in Gothenburg's intermediate city areas. The four case areas are representative areas of a hybrid situation between the urban and the suburban with different socio-economic profiles and levels of density and car-dependency. While the use of demographic statistics (traditional data sources) was helpful to describe and situate the case areas within the intermediate city debate, the analysis of geolocated SMD as a form of innovative data sources enabled a direct exploration of urban activity. This finding supports previous research claiming the value of SMD for identifying attractive public and semi-public urban spaces (Ilieva and McPhearson 2018).

Both traditional and innovative data sources produced interesting results. Some interesting findings emerged from the statistical data. One regards the low motorization rate of the high-rise area Hammarkullen compared to the somewhat similar area Flatås, both being large-scale housing areas. On the one hand, the lower income levels in Hammarkullen may explain this finding but, still, the car ownership in Flatås exceeds both of the higher income areas Skår and Kålltorp. On the other hand, Hammarkullen is located furthest away from the city centre of the four case areas, which would be a factor contributing to car ownership. Nevertheless, it seems as if inhabitants are not subjected to forced car ownership (Curl et al. 2018) to meet their mobility needs. Also, calculating population and dwelling density based on the administrative primary areas (at times including vast unbuilt areas) and the buffer-zone approach, respectively, affected the perception of the densities of the four case areas significantly. This is a promising avenue for contributing to previous research (e.g. Berghauser Pont and Haupt 2009) in continued studies on urban compactness.

Although statistical data were used in this paper mostly for descriptive purposes of the case areas, some interesting evidence has also emerged from the comparison 
Table 9 Google Places and Foursquare obtained Third Places by neighbourhood

\begin{tabular}{|c|c|}
\hline \multicolumn{2}{|c|}{ GOOGLE PLACES CATEGORIES } \\
\hline Whird places & Average of GP \\
\hline Flatås & 2,6 \\
\hline // Deli/local supermarket & 4,0 \\
\hline Lidl & 4,0 \\
\hline$/ /$ [new] Hospital & 3,9 \\
\hline Hogsbo Sjukhus & 3,9 \\
\hline // Restaurants and cafes & 3,7 \\
\hline La Piazza & 3,7 \\
\hline // Schools, college, universities & 3,3 \\
\hline Flatasskolan & 3,3 \\
\hline // [new] Station & 1,0 \\
\hline Armlangdsgatan & 0,0 \\
\hline Synhallsgatan & 3,0 \\
\hline Tvarhandsgatan & 0,0 \\
\hline Hammarkullen & 2,6 \\
\hline // Schools, college, universities & 4,0 \\
\hline Folkhogskolan i Angered & 5,0 \\
\hline Forskola & 3,7 \\
\hline Nytorpsskolan & 3,6 \\
\hline // [new] Gas station & 3,4 \\
\hline OKQ8 & 3,4 \\
\hline // [new] Station & 2,9 \\
\hline Hammarkullen & 5,0 \\
\hline Hjallbovallen & 0,0 \\
\hline Sandeslattsgatan & 3,8 \\
\hline // [new] Parking & 0,0 \\
\hline Hammarkulletorget & 0,0 \\
\hline Sandeslattsgatan & 0,0 \\
\hline // Neighbourhood & 0,0 \\
\hline Hammarkullen & 0,0 \\
\hline Kålltorp & 4,1 \\
\hline // Recreation centers & 5,0 \\
\hline Kalltorps fritidsgard & 5,0 \\
\hline // Coffee shops & 4,6 \\
\hline Portens bageri & 4,6 \\
\hline // Restaurants and cafes & 4,3 \\
\hline Pizza Roma & 4,3 \\
\hline Pizzabageriet & 4,3 \\
\hline Sannegardens Pizzeria & 4,3 \\
\hline$/ /$ [new] Gym & 4,3 \\
\hline Skatas & 4,3 \\
\hline // Parks and outdoor recreation & 4,1 \\
\hline Apslatten & 4,2 \\
\hline Lisebergsbyn & 4,0 \\
\hline // Schools, college, universities & 3,9 \\
\hline Kalltorpsskolan & 3,9 \\
\hline // [new] Gas station & 3,9 \\
\hline Circle K & 3,9 \\
\hline // Bars and pubs & 3,8 \\
\hline Glenn Sportsbar & 3,3 \\
\hline Olstugan Tullen Kalltorp & 4,2 \\
\hline // Deli/local supermarket & 3,8 \\
\hline Coop Konsum & 3,4 \\
\hline Systembolaget & 4,1 \\
\hline Tempo & \\
\hline Skår & 3,3 \\
\hline // [new] Station & 5,0 \\
\hline Kallebacksvagen & 5,0 \\
\hline Skars kyrka & 5,0 \\
\hline // [new] Banks & 4,5 \\
\hline SEB & 4,5 \\
\hline // Coffee shops & 4,3 \\
\hline Goteborgs Pepparkaksbageri & 4,3 \\
\hline // [new] Gas station & 3,8 \\
\hline St1 & 3,8 \\
\hline // Restaurants and cafes & 3,5 \\
\hline Thai Samila & 3,5 \\
\hline // Neighbourhood & 0,0 \\
\hline Skar & 0,0 \\
\hline // Churches & 0,0 \\
\hline Skars kyrka & 0,0 \\
\hline
\end{tabular}

\begin{tabular}{|c|c|c|c|}
\hline \multirow[t]{2}{*}{ Third places } & \multicolumn{2}{|c|}{ FOURSQUARE CATEGORIES } & \multirow[b]{2}{*}{ Sum of Users } \\
\hline & Sum of Checkins & Sum of Visits & \\
\hline Kålltorp & 2110 & 6275 & 2324 \\
\hline // [new] Gas station & 472 & 1359 & 508 \\
\hline Circle K & 472 & 1359 & 508 \\
\hline // [new] Hotels & 293 & 646 & 374 \\
\hline Lisebergsbyn & 293 & 646 & 374 \\
\hline // Bars and pubs & 258 & 967 & 393 \\
\hline Glenn Sportsbar & 195 & 655 & 232 \\
\hline Olstugan Tullen Kalltorp & 63 & 312 & 161 \\
\hline // Coffee shops & 30 & 194 & 92 \\
\hline Portens Bageri & 30 & 194 & 92 \\
\hline // Deli/local supermarket & 783 & 2509 & 656 \\
\hline Coop Konsum & 317 & 993 & 228 \\
\hline Systembolaget & 424 & 1422 & 398 \\
\hline Tempo & 42 & 94 & 30 \\
\hline // Parks and outdoor recreation & 80 & 133 & 82 \\
\hline Apslatten & 80 & 133 & 82 \\
\hline // Recreation centers & 10 & 22 & 9 \\
\hline Kalltorps fritidsgard & 10 & 22 & 9 \\
\hline // Restaurants and cafes & 87 & 207 & 119 \\
\hline Pizza Roma & 35 & 103 & 59 \\
\hline Pizzabageriet & 36 & 60 & 33 \\
\hline Sannegardens Pizzeria & 16 & 44 & 27 \\
\hline // Schools, colleges, universities & 97 & 238 & 91 \\
\hline Kalltorpsskolan & 97 & 238 & 91 \\
\hline Skår & 449 & 925 & 423 \\
\hline$/ /$ [new] Banks & 40 & 160 & 85 \\
\hline SEB & 40 & 160 & 85 \\
\hline // [new] Gas station & 156 & 415 & 175 \\
\hline St1 & 156 & 415 & 175 \\
\hline // Coffee shops & 12 & 38 & 15 \\
\hline Goteborgs Pepparkaksbageri & 12 & 38 & 15 \\
\hline // Neighbourhood & 145 & 182 & 75 \\
\hline Skar & 145 & 182 & 75 \\
\hline // Restaurants and cafes & 96 & 130 & 73 \\
\hline Thai Samila & 96 & 130 & 73 \\
\hline Flatås & 323 & 1831 & 571 \\
\hline // [new] Hospital & 75 & 148 & 53 \\
\hline Hogsbo Sjukhus & 75 & 148 & 53 \\
\hline$/ /[$ new] Station & 70 & 128 & 48 \\
\hline Armlangdsgatan & 23 & 49 & 18 \\
\hline Synhallsgatan & 23 & 47 & 20 \\
\hline Tvarhandsgatan & 24 & 32 & 10 \\
\hline // Deli/local supermarket & 99 & 1194 & 346 \\
\hline Lidl & 99 & 1194 & 346 \\
\hline // Restaurants and cafes & 23 & 131 & 67 \\
\hline La Piazza & 23 & 131 & 67 \\
\hline // Schools, colleges, universities & 56 & 230 & 57 \\
\hline Flatasskolan & 56 & 230 & 57 \\
\hline Hammarkullen & 131 & 215 & 117 \\
\hline // Neighbourhood & 98 & 140 & 70 \\
\hline Hammarkullen & 98 & 140 & 70 \\
\hline // Parks and outdoor recreation & 31 & 53 & 35 \\
\hline Hjallbovallen & 31 & 53 & 35 \\
\hline // Schools, colleges, universities & 2 & 22 & 12 \\
\hline Folkhogskolan i Angered & 1 & 1 & 1 \\
\hline Nytorpsskolan & 1 & 21 & 11 \\
\hline Grand Total & 3013 & 9246 & 3435 \\
\hline
\end{tabular}

between statistics and SMD. One observation was that regarding the number of LBSN datapoints per inhabitant in the four case areas, Hammarkullen comes out significantly lower than the other three areas. One explanation could be that the less the presence of 


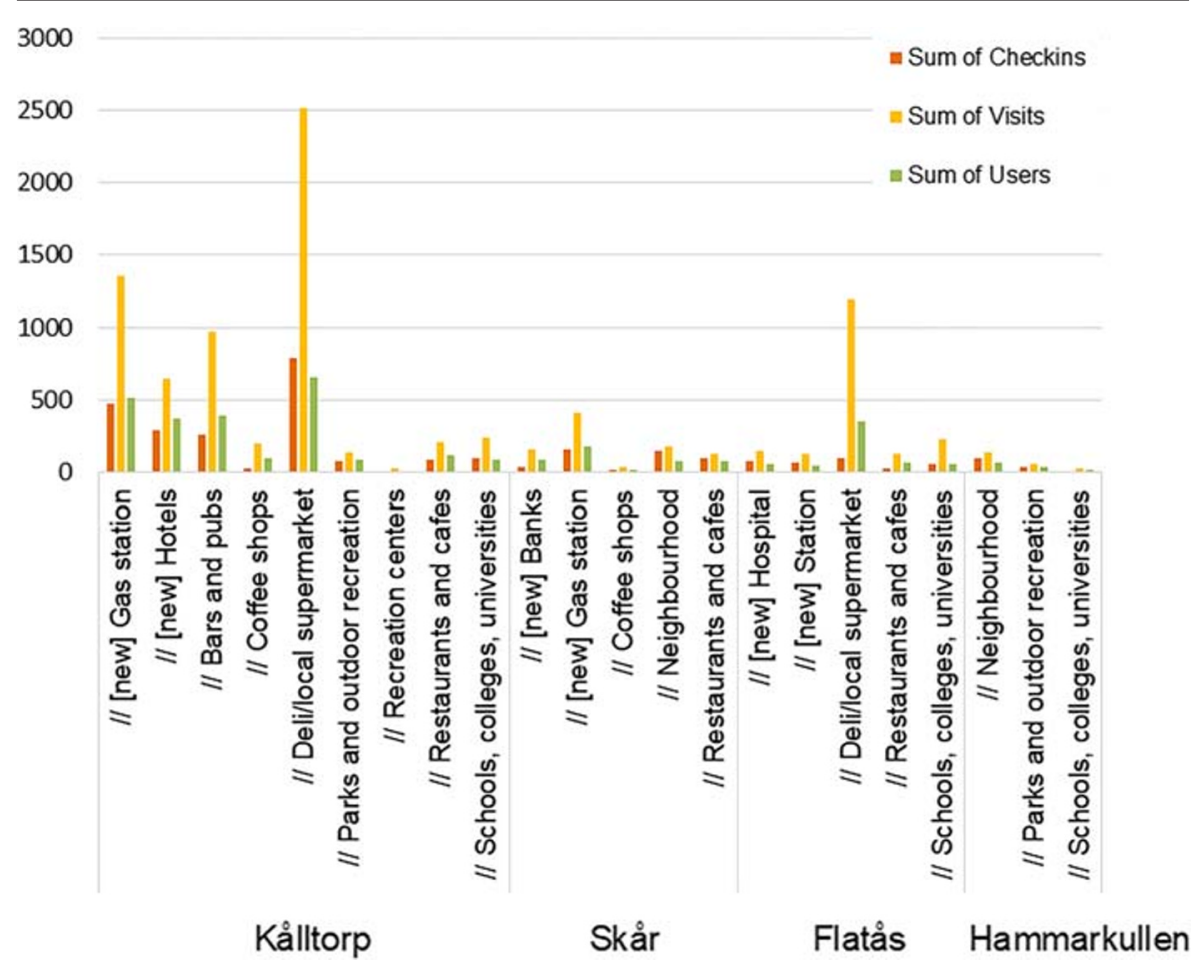

Fig. 11 Number of check-ins, visits and users per Third Places category types by neighbourhood according to Foursquare

urban activity is in an area, the less LBSN data is available, but another assumption is that the use of social media is lower in Hammarkullen, e.g. due to lower incomes and other socioeconomic challenges. However, other studies show that Internet access and social media use is not necessarily lower in socioeconomically disadvantaged groups (Lohse 2013; Literat and Brough 2019). Another concern would then be if the

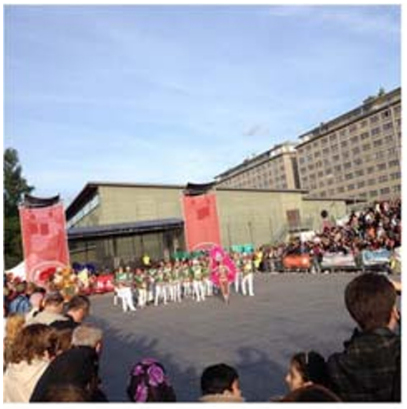

\section{Hammarkullen} (Neighbourhood)

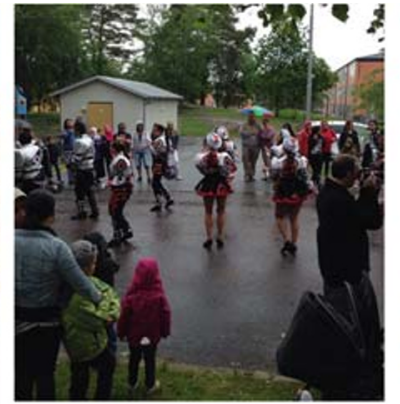

Hammarkulletorget (Outdoor Plaza)

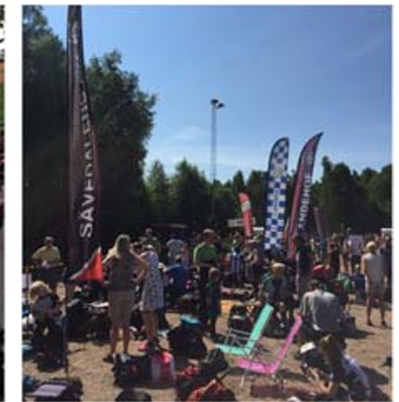

Hjällbovallen (Soccer Field)

Fig. 12 From left to right, user-shared images in foursquare webpage of the three-top ranked Third Places in Hammarkullen. (source: Foursquare City guide https://es.foursquare.com/city-guide) 
inhabitants of Hammarkullen - having a diverse ethnical background - engage with other social media platforms (e.g. Snapchat, Instagram, Tumblr, Telegram) and thus become misrepresented in the present study. If this is the case, more research is needed to secure a just representation of Third Places across different types of neigbourhoods and user groups (Toivonen et al. 2019).

From a methodological perspective, although SMD are easily accessible, they typically lack important background information that may affect sentiments and movement patterns, such as socioeconomic status - e.g. age, ethnicity, gender, education, income, occupation - (Ilieva and McPhearson 2018) and in particular where the informants live and work (Huang and Wong 2016). The present study went to some length to link the number of LBSN datapoints to the mean income levels and social diversity of neighborhoods, but evidently much more consideration needs to be taken to socioeconomic aspects. On the flipside, such retrieval of personal information from combined data sources leads to privacy concerns (Ilieva and McPhearson 2018). Still, it was found that in Hammarkullen, the case area with the lowest car ownership and the lowest income level but the highest ethnic diversity among the four selected case areas, local inhabitants have highlighted the importance of public open space through their SMD. In other more affluent case areas, such as Kålltorp and Skår, indoor facilities become more important. In terms of specific activities, a peculiar example is represented by Kålltorp and Skår. In such two areas, whose motorization rate is around or above the city level, the gas station is included among the most visited Foursquare places. Then again, Swedish gas stations tend to provide quite a selection of foodstuffs, thus serving as local supermarkets. Further research is needed to better understand the correlations and cause-effect relations of the statistical variables and SMD. This appears to be consistent with other studies having found that Third Places potentially are more important in poorer neighbourhoods while richer populations might prefer more commodified modes of consumption of public space (e.g. Williams and Hipp 2019).

Moreover, opposed to Big Data studies the use of SMD and LBSNs in small-scale studies, such as this one, must give due consideration to thorough manual validation and verification of data for three main reasons. First, there are precision limitations of GPS as was observed in the collected data in the form of different geographical points corresponding to the same venue/place. Also, for different reasons (e.g. aspirations or dispositions to visit a location) people may tag social media input with other locations than their actual location when posting that input (Toivonen et al. 2019). Second, the sentiments and behaviours people attach or tag to places in their SMD may be different from what they actually think and do due to social pressures and desirabilities (Ilieva and McPhearson 2018). Third, because Third Places tend to be quotidian spaces and establishments and tend to be related to people's routine activities such as work or grocery shopping, people may simply forget to check-in or rate a space (Zhang et al. 2013).

The stance taken by this paper recognises both the importance of technology for today's socialization, and the relevance of the online-offline nature of the social interaction as contributors to the existence of Third Places in the city, and even to the existence of fully virtual Third Places (Mcarthur and White 2016). However, this position does not necessarily concur with that of Oldenburg's view, which considers technology as a potential threat to community building. He argues that "the only predictable social consequence of technological advancement is that [individuals] will grow ever more apart from one another" (Oldenburg 1989: 25). 
The types of Third Places nowadays have evolved from those identified in previous decades. The fast-paced life of urban individuals results in Third Places that may be "on the way" between work and home, i.e. the Gas station in Skår and Kålltorp. This study confirms the hypothesis that the physical neighborhood's Third Places can be identified through analysing LBSN data even if users of social media are a minority of the whole population (Ren et al. 2019). Precisely, the consideration of Third Places as those Google Places places that are also registered as Foursquare venues is, arguably, a starting point for acknowledging informal gathering places and establishments that are worth studying further as there are online traces of social activity.

The study also found that Foursquare, Google Places and Twitter data complement and validate each other. Indeed, they are complementary as their datasets give rise to different variables, where the information found in one social network enriches that of another. As observed in Table 9, even though most of the places and establishments coincide in both Google Places and Foursquare datasets, there were some variations that had to be analysed further. For instance, i.e. cases in which a venue in Foursquare corresponding to a building may coincide with one in Google Places and also have two or more places or venues registered at the same premise. That is the case of the Sport Centre building Skatås motionscentrum in Kålltorp, which appears twice in Google Places dataset as "Skatås" and coincides with the georeferenced point in Foursquare Café Skatåsmålet, a coffee area within the Gym. In this specific case, the sports centre itself is considered as the Third Place.

Furthermore, the findings evidence that results obtained from one social network were reinforced by the other two. For instance, in the case of an area in Kalltorp (see Fig. 13) where there is a concentration of activity found in both Google Places and Foursquare, a specific Third Place was identified: the coffee place Portens bageri, that was also mentioned in a Tweet - "Har precis lagt upp ett foto @ Portens Bageri.

The findings regarding the type of Third Places in the four analysed neighbourhoods show that almost half of them do not necessarily coincide with what Mehta and Bosson consider as a Third Place, i.e. a "business on the Main Street that was identified as a community-gathering place by people who lived or worked in the neighbourhood" (2010: 10). Instead, this study confirms Oldenburg's discussion on how Third Places should include more than businesses as they can be other types of spaces for informal public and

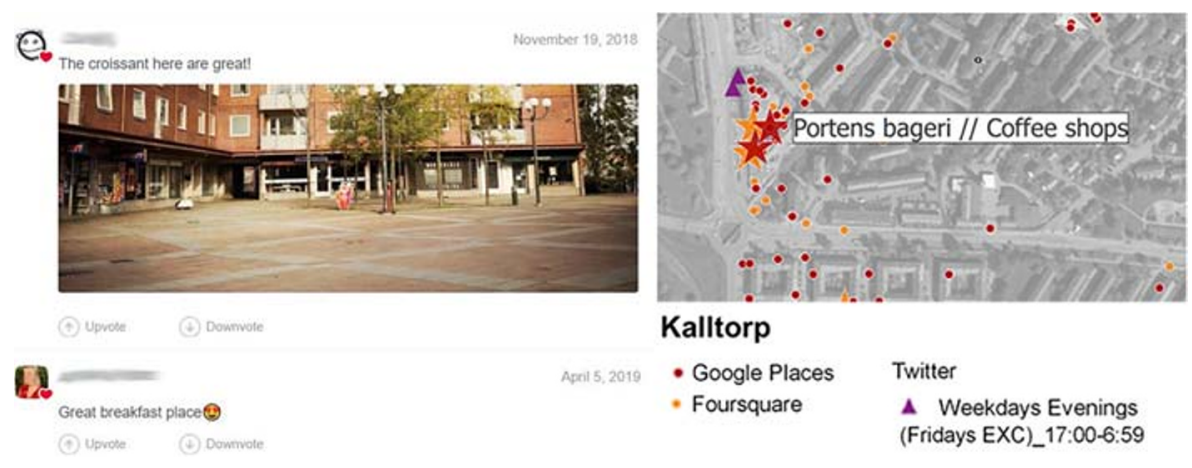

Fig. 13 The Kålltorp third Place Portens bageri. Left-hand side picture- a photo and a comment shared in the foursquare website; and, right-hand side diagram- the concentration of venues, places and tweets of the Portens bageri surrounding area (source: Foursquare City guide https://es.foursquare.com/city-guide) 
social life (Oldenburg 1989). Places categories that may not initially be considered social spaces (e.g. parking lots) were found to have a degree of social activity. For instance, Sandeslättsgatan in Hammarkullen is a parking lot with a basketball court, which is potentially the reason why it appears to be an outdoor Third Place. The importance of outdoor and transportation related types of Third Places should thus be highlighted. Recognising these types of public spaces, where a degree of daily social activity occurs, is valuable for the formulation of urban plans and planning policies. It may be the case that these spaces and their surroundings could be targeted for regeneration to benefit existing social life and future community building. This brings forward the need to analyse also the specific spatial conditions on site, to be able to fully interpret the LBSN data and better understand urban qualities leading to Third Places.

Notwithstanding the above-mentioned opportunities to identify urban activity and Third Places in the intermediate areas of the city through SMD, there are some recognised limitations as discussed above. In this respect, just as in other studies, such as that of Boy and Uitermark (2016), this study's main purpose is to demonstrate how these data can shed new light on traditional urban issues. Using different LBSN sources, but also other types of data, for cross-validation purposes is more likely to provide a more accurate picture as opposed to relying only on a single source or single type of data. In this way, LBSNs can be considered as valuable sources that provide valuable complementarity to traditional studies. They introduce a valid virtual layer of social activities which has been demonstrated to be representative of the physical reality.

Funding Information Open access funding provided by Chalmers University of Technology. This study was funded by Svenska Forskningsrådet Formas (grant number 2016-20097) and Adlerbertska Stiftelserna (grant number 2017).

\section{Compliance with Ethical Standards}

Conflict of Interest The authors declare that they have no conflict of interest.

Open Access This article is licensed under a Creative Commons Attribution 4.0 International License, which permits use, sharing, adaptation, distribution and reproduction in any medium or format, as long as you give appropriate credit to the original author(s) and the source, provide a link to the Creative Commons licence, and indicate if changes were made. The images or other third party material in this article are included in the article's Creative Commons licence, unless indicated otherwise in a credit line to the material. If material is not included in the article's Creative Commons licence and your intended use is not permitted by statutory regulation or exceeds the permitted use, you will need to obtain permission directly from the copyright holder. To view a copy of this licence, visit http://creativecommons.org/licenses/by/4.0/.

\section{References}

Adelfio M. (2016) Socially Sustainable Suburbia: Addressing a Puzzling and Multifaceted Issue, Artículo Journal of Urban Research, 13.

Agryzkov, T., Martí, P., Nolasco-Cirugeda, A., Serrano-Estrada, L., Tortosa, L., \& Vicent, J. F. (2016a). Analysing successful public spaces in an urban street network using data from the social networks foursquare and Twitter. Applied Network Science, 1(12), 1-15. https://doi.org/10.1007/s41109-016-0014-z. 
Agryzkov, T., Martí, P., Tortosa, L., \& Vicent, J. F. (2016b). Measuring urban activities using foursquare data and network analysis: A case study of Murcia (Spain). International Journal of Geographical Information Science, 31(1), 1-22. https://doi.org/10.1080/13658816.2016.1188931.

Aiello, L. M., Schifanella, R., Quercia, D., \& Aletta, F. (2016). Chatty maps: Constructing sound maps of urban areas from social media data. Royal Society Open Science, 3(150690). https://doi.org/10.1098 /rsos.150690.

Apparicio, P., Martori, J. C., Pearson, A. L., Fournier, E., \& Apparicio, D. (2014). An open-source software for calculating indices of urban residential segregation. Social Science and Computer Review, 32(1), 117-128.

Berghauser Pont, M., \& Haupt, P. (2009) Space, Density and Urban Form. (PhD). Technische Universiteit Delft, Delft.

Bergman, B. 2008. E4-staden: det trafikala stadslandskapet längs E4: an genom Stockholm. Stockholm: Stockholmia.

Bollens, S. A. (1988). Municipal decline and inequality in American suburban rings, 1960-1980. Regional Studies, 22(4), 277-285.

Boy, J. D., \& Uitermark, J. (2016). How to study the City on Instagram. PLoS One, 11(6). https://doi. org/10.1371/journal.pone.0158161.

Boyko, C. T., \& Cooper, R. (2011). Clarifying and re-conceptualising density. Progress in Planning, 76(1), 161.

Buchel, O., \& Rasmussen Pennington, D. (2017). Geospatial analysis. In L. Sloan \& A. Quan-Haase (Eds.), The SAGE handbook of social media research methods (pp. 285-308). London: SAGE Publications Ltd..

Burton, E. 2002. Measuring urban compactness in UK towns and cities. Environment and Planning B: Planning and Design 2002, 29(1), 219-250.

Campagna, M. (2016a). Social Media Geographic Information: Why social is special when it goes spatial? In European Handbook of Crowdsourced Geographic Information (pp. 45-54). https://doi.org/10.5334/bax.

Campagna, M. (2016b). Social Media Geographic Information : Why Social Is Special When It Goes Spatial ? In European Handbook of Crowdsourced Geographic Information (pp. 45-54). https://doi.org/10.5334/bax.

Cerrone, D. A sense of place. Exploring the potentials and possible uses of location based social network data for urban and transportation planning in Turku city Centre (2015). Turku.

City of Gothenburg (2014) Development strategy Gothenburg 2035. The Planning and Building Authority, Gothenburg.

Churchman, A. (1999). Disentangling the concept of density. Journal of Planning Literature 13(4), 389-411.

Coldwell, F. (2017) Party central: Gothenburg voted world's most sociable city, The Guardian, 22 Feb 2017. https:/www.theguardian.com/travel/2017/feb/22/party-gothenburg-voted-worlds-most-sociable-cityhostelworld-stockholm-new-york. Accessed: 26 Aug 2019.

Curl, A., Clark, J., \& Kearns, A. (2018). Household car adoption and financial distress in deprived urban communities: A case of forced car ownership? Transport Policy, 65, 61-71. https://doi.org/10.1016/j. tranpol.2017.01.002.

Dantzig, George B. \& Thomas Lorie Saaty 1973. Compact City: Plan for a Liveable Urban

Díaz-Pacheco J. and García-Palomares J. C. (2014). Urban sprawl in the Mediterranean urban regions in Europe and the crisis effect on the urban land Development: Madrid as Study Case. Urban Studies Research. https://doi.org/10.1155/2014/807381.

Dieleman, F., \& Wegener, M. (2004). Compact City and urban sprawl. Built Environment (1978-), 30(4), 308-323.

Dingil, A., Rupi, F., Schweizer, J., Stasiškienè, Ž., \& Aalipour, K. (2019). The role of culture in urban travel patterns: Quantitative analyses of urban areas based on Hofstede's culture dimensions. Social sciences, 8, 227. https://doi.org/10.3390/socsci8080227.

Downs, A. (1981). Neighborhoods and urban development. Washington, DC: The Brookings Institution.

Drier, P. (1996). The struggle for out cities. Social Policy, 26(4), 9-24.

Duany, A., Plater-Zyberk, E., \& Speck, J. (2000). Suburban nation: The rise of sprawl and the decline of the American dream. New York: North Point Press.

EEA-FOEN (2016). Urban sprawl in Europe, EEA-FOEN.

EU Ministers (2007). Leipzig Charter on Sustainable European Cities. Final draft (2 May 2007). http://ec. europa.eu/regional_policy/archive/themes/urban/leipzig_charter.pdf. Accessed: 1 August 2019.

Foursquare Inc. (2018). API- Get details of a venue. https://developer.foursquare.com/docs/api/venues/details

Frank, M. R., Mitchell, L., Dodds, P. S., \& Danforth, C. M. (2013). Happiness and the patterns of life: A study of geolocated tweets. Scientific Reports, 3, 1-9. https://doi.org/10.1038/srep02625.

Fu, C., McKenzie, G., Frias-Martinez, V., \& Stewart, K. (July 2017). (2018). Identifying spatiotemporal urban activities through linguistic signatures. Computers. Environment and Urban Systems, 72, 25-37. https://doi.org/10.1016/j.compenvurbsys.2018.07.003. 
García-Palomares, J. C., Salas-Olmedo, M. H., Moya-Gómez, B., Condeço-Melhorado, A., \& Gutiérrez, J. (2018). City dynamics through Twitter: Relationships between land use and spatiotemporal demographics. Cities, 72, 310-319. https://doi.org/10.1016/j.cities.2017.09.007.

Gerbaudo, P. (2016). Rousing the Facebook crowd: Digital enthusiasm and emotional contagion in the 2011 protests in Egypt and Spain, 10, 254-273.

Goodchild, M. F. (2007). Citizens as sensors: Web 2.0 and the volunteering of geographic information. GeoFocus, 7, 8-10. https://doi.org/10.1007/s10708-008-9190-4.

Google Developers. (2019). Google Places API Web Service. https://developers.google.com/places/webservice/intro. .

Górgolas, P. (2018). El reto de compactar la periferia residencial contemporánea: densificación eficaz, centralidades selectivas y diversidad funcional, ACE: Architecture, City and Environment = Arquitectura. Ciudad y Entorno, 13(38), 56-80.

Greater London Authority - GLA (2002), A City of Villages: Promoting a sustainable future for London's suburbs, Technical Report, Greater London Authority.

Hanlon B. (2015). Beyond sprawl: Social sustainability and reinvestment in the Baltimore suburbs, in Anacker K (ed.) The new American suburb: Poverty, race and the economic crisis. London, Routledge.

Healey, P. (2011). The universal and the contingent: Some reflections on the transnational flow of planning ideas and practices. Planning Theory. doi:https://doi.org/10.1177/1473095211419333.

Hofstad, H. (2012). Compact city development: High ideals and emerging practices. European journal of spatial development. Refereed article no. 49. http://archive. Nordregio.Se/global/EJSD/ refereed\%20articles/refereed49. Pdf. Accessed: 1 October 2018.

Huang, Q., \& Wong, D. W. S. (2016). Activity patterns, socioeconomic status and urban spatial structure: What can social media data tell us? International Journal of Geographical Information Science, 30(9), 126. https://doi.org/10.1080/13658816.2016.1145225.

Huang, L., Ma, Y., \& Liu, Y. (2015). Point-of-interest recommendation in location-based social networks with personalized geo-social influence. China Communications, 12(12), 21-31. https://doi.org/10.1109 /CC.2015.7385525.

Hudnut, W. H. (2003). Halfway to everywhere: A portrait of America's first tier suburbs. Washington, DC: Urban Land Institute.

Ilieva, R. T., \& McPhearson, T. (2018). Social-media data for urban sustainability. Nature Sustainability, 1, 553-565. https://doi.org/10.1038/s41893-018-0153-6.

Jackson, K. T. (1985). Crabgrass frontier: The suburbanization of the United States. New York: Oxford University Press.

Jacobs, J. (1961), The death and life of Great American cities, New York: Random House.

Jeffres, L. W., Bracken, C. C., Jian, G., \& Casey, M. F. (2009). The impact of third places on community quality of life. Applied Research Quality Life, 4, 333-345. https://doi.org/10.1007/s11482-009-9084-8.

Jenks, M., Burton, E., \& Williams, K. (eds.) 1996. The Compact City: A Sustainable Urban Form? London: Spon.

Jiang, Y., Li, Z., \& Ye, X. (2018). Understanding demographic and socioeconomic biases of geotagged Twitter users at the county level. Cartography and Geographic Information Science, 1-15. https://oi. org/10.1080/15230406.2018.1434834.

Kain, J.-H., J. Stenberg, M. Adelfio, M. Oloko, L. Thuvander, P. Zapata, and M. J. Zapata Campos. 2016. Assumed Qualities of Compact Cities: Divergences Between the Global North and the Global South in the Research Discourse, 17th N-AERUS Conference Proceedings. Gothenburg, Sweden.

Keil, R., \& Young, D. (2009). Fringe explosions: Risk and vulnerability in Canada's new in-between urban landscape. The Canadian Geographer / Le Géographe canadien, 53, 488-499. https://doi.org/10.1111 j.1541-0064.2009.00270.x.

Kirby, A., \& Modarres, A. (2010). The suburban question. Cities. The International Journal of Urban Policy and Planning, 27(2), 114-121.

Lawton, P., \& Punch, M. (2014). 'European city' ideals and realities in Dublin. International Journal of Urban and Regional Research, 38, 864-885.

Literat, I., \& Brough, M. (2019). From ethical to equitable social media technologies: Amplifying underrepresented youth voices in digital technology design. Journal of Media Ethics, 34(3), 1-14. https://doi. org/10.1080/23736992.2019.1638259.

Lohse, B. (2013). Facebook is an effective strategy to recruit low-income women to online nutrition education. Journal of Nutrition Education and Behavior, 45(1), 69-76. https://doi.org/10.1016/j.jneb.2012.06.006.

Martí, P., Serrano-Estrada, L., \& Nolasco-Cirugeda, A. (2017). Using locative social media and urban cartographies to identify and locate successful urban plazas. Cities, 64. https://doi.org/10.1016/j. cities.2017.02.007. 
Martí, P., Serrano-Estrada, L., \& Nolasco-Cirugeda, A. (2019). Social media data: Challenges, opportunities and limitations in urban studies. Computers, Environment and Urban Systems, 74, 161-174. https://doi. org/10.1016/j.compenvurbsys.2018.11.001.

Martínez, M. P. L., Berrozpe, T. I., \& Lasarte, M. P. (2014). Image-focused social media for a market analysis of tourism consumption. International Journal of Technology Management, 64(1), 17. https://doi. org/10.1504/IJTM.2014.059234.

Mayr, P., \& Weller, K. (2017). Think before you collect: Setting up a data collection approach for social media studies. In L. Sloan \& A. Quan-Haase (Eds.), The SAGE handbook of social media research methods (pp. 108-124). London: SAGE Publications Ltd..

Mcardle, G., Furey, E., Lawlor, A., \& Pozdnoukhov, A. (2014). Using digital footprints for a City-scale traffic simulation. ACM Transactions on Intelligent Systems and Technology, 5(3), 1-16. https://doi.org/10.1145 12517028

Mcarthur, J. A., \& White, A. F. (2016). Twitter chats as third Places: Conceptualizing a Digital Gathering Site. https://doi.org/10.1177/2056305116665857.

Mehta, V., \& Bosson, J. K. (2010). Third places and the social life of streets. Environment and Behavior, 42(6), 779-805. https://doi.org/10.1177/0013916509344677.

Memarovic, N., Fels, S., Anacleto, J., Calderon, R., Gobbo, F., \& Carroll, J. M. (2014). Rethinking third places: Contemporary design with technology. The Journal of Community Informatics, 10(3).

Miniwatts Marketing Group. (2016). Internet world stats. Usage and population statistics. http://www. internetworldstats.com/europa.htm\#es. Accessed 13 June 2016.

Moliní, F. \& Salgado, M. (2012). Los impactos ambientales de la ciudad de baja densidad en relación con los de la ciudad compacta. Biblio 3W. Revista Bibliográfica de Geografia y Ciencias Sociales. Vol. XVII, $n^{\circ}$ 958. http://www.ub.edu/geocrit/b3w-958.htm. Accessed 4 November 2019.

Morandi, C., Palmieri, R., \& Tomarchio, L. (2014). Digital social media to enhance the public realm in historic cities. In Aiello, L. M. \& McFarland, D. (Eds.), Social Informatics (SocInfo 20., Vol. 1, p. 34ß39). Springer. https://doi.org/10.1007/978-3-319-13734-6.

Mumford, L. (1937). What is a City. Architectural Record, 91-95.

National Association of Home Builders (NAHB) (2002). Smart growth, smart choices. Washington, DC: National Association of Home Builders.

Neuman, M. (2005). The compact city fallacy. Journal of Planning Education and Research, 25, 11-26.

Oldenburg, R. (1989). The Great good Place: Cafes, coffee shops, community centers, beauty parlors, general stores, bars. Hair Salons and Other Hangouts at the Heart of a Community. Marlowe and Company, 311.

Oldenburg, Ray. (2001). Celebrating the third place: Inspiring stories about the "Great good places" at the heart of our communities. New York: Da Capo Press.

Oldenburg, R., \& Brissett, D. (1982). The third place. Qualitative Sociology, 5(4), 265-284. https://doi. org/10.1007/BF00986754.

Oldenburg, Ray, Kaplan, M., Great, T., Place, G., Books, H., Oldenburg, R., et al. (1999). The great good place (second.). Cambridge (Massachusetts): Da Capo Press.

Orfield, M. (1997). Metropolitics: A regional agenda for community stability. Washington, DC: The Brookings Institution.

Quercia, D., Aiello, L. M., Mclean, K., \& Schifanella, R. (2015). Smelly maps: The digital life of urban Smellscapes. In Ninth International AAAI Conference on Web and Social Media. Oxford: AAAI Publications.

Rani, W. M., \& Mardiah, W. M. (2015). Compact urban form for sociability in urban neighbourhoods. International Journal of Social Science and Humanity, 5(10), 822-826.

Ren, Z., Jiang, B., \& Seipel, S. (2019). Capturing and characterizing human activities using building locations in America. ISPRS International Journal of Geo-Information, 8(5). https://doi.org/10.3390/ijgi8050200.

Rogers, Y., \& Brignull, H. (2002). Subtle ice-breaking: Encouraging socializing and interaction around a large public display. Workshop on Public, Community. and Situated Displays, 1-6. https://doi.org/10.2169 /internalmedicine.43.527.

Saaty, T. L. (2013). Compact City: The next urban evolution in response to climate change. Pittsburg, PA: RWS Publications.

Salas-Olmedo, M. H., Moya-Gómez, B., García-Palomares, J. C., \& Gutiérrez, J. (2018). Tourists’ digital footprint in cities: Comparing big data sources. Tourism Management, 66, 13-25. https://doi.org/10.1016 /j.tourman.2017.11.001.

SCB. (2019). Statistics Sweden. https://www.scb.se/en/. Accessed 17 June 2019.

Serrano-Estrada, L., Nolasco-Cirugeda, A., \& Martí, P. (2016). Comparing two residential suburban areas in the Costa Blanca. Spain. Articulo. Journal of Urban Research, 13(13). https://doi.org/10.4000 /articulo.2935. 
Sieverts, T. (2003), Cities without cities: An interpretation of the Zwischenstadt, London and New York: Routledge.

Steiger, E., Westerholt, R., Resch, B., \& Zipf, A. (2015). Twitter as an indicator for whereabouts of people? Correlating Twitter with UK census data. Computers, Environment and Urban Systems, 54, 255-265. https://doi.org/10.1016/j.compenvurbsys.2015.09.007.

Steinkuehler, C. A., \& Williams, D. (2006). Where everybody knows your (screen) name: Online games as 'third places'. Journal of Computer-Mediated Communication, 11(4), 885-909. https://doi.org/10.1111 j.1083-6101.2006.00300.x.

Stevenson, D. 2003. Cities and urban cultures. Philadelphia, Open University Press.

Sundborg, P. (2001). Stadsplanen och marknaden. Clarté, 3(01).

Toivonen, T., Heikinheimo, V., Fink, C., Hausmann, A., Hiippala, T., Järv, O., Tenkanen, H., \& Di Minin, E. (2019). Social media data for conservation science: A methodological overview. Biological Conservation, 233, 298-315. https://doi.org/10.1016/j.biocon.2019.01.023.

UN-Habitat. 2012. Urban Patterns for a Green Economy: Leveraging Density. https://unhabitat.org/wpcontent/uploads/2014/06/Leveraging-Density-Urban-Patterns-for-a-Green-Economy.pdf (accessed 18 October 2018).

Van Canneyt, S., Schockaert, S., Van Laere, O., \& Dhoedt, B. (2012). Detecting places of interest using social media. In 2012 IEEE/WIC/ACM International Conferences on Web Intelligence and Intelligent Agent Technology (pp. 447-451). Macau. https://doi.org/10.1109/WI-IAT.2012.19.

Van Weerdenburg, D., Scheider, S., Adams, B., Spierings, B., \& van der Zee, E. (2019). Where to go and what to do: Extracting leisure activity potentials from web data on urban space. Computers, Environment and Urban Systems, 73(August 2018), 143-156. https://doi.org/10.1016/j.compenvurbsys.2018.09.005.

Vicenzotti, V., and M. Qviström. 2018. "Zwischenstadt as a Travelling Concept: Towards a Critical Discussion of Mobile Ideas in Transnational Planning Discourses on Urban Sprawl.” European Planning Studies 26: 115-132. https://doi.org/10.1080/09654313.2017.1375082.

Walks, A. (2013). Suburbanism as a way of life, slight return. Urban Studies, 50(8), 1471-1488.

Westerink, J., Haase, D., Bauer, A., Ravetz, J., Jarrige, F., \& Aalbers, C. B. E. (2013). Dealing with sustainability trade-offs of the Compact City in Peri-urban planning across European City regions. European Planning Studies, 21(4), 473-497.

Williams, S. A., \& Hipp, J. R. (2019). How great and how good?: Third places, neighbor interaction, and cohesion in the neighborhood context. Social Science Research, 77, 68-78. https://doi.org/10.1016/j. ssresearch.2018.10.008.

World Bank. 2009. World Development Report 2009: Reshaping Economic Geography. Washington, DC: World Bank

Ye, L. (2008), Urban sprawl, amenities and quality of life, VDM Verlag Dr. Müller.

Yoon, J., Oishi, J., Nawyn, J., Kobayashi, K., \& Gupta, N. (2004). FishPong: Encouraging human-to-human interaction in informal social environments. In Proceedings of the 2004 ACM conference on Computer supported cooperative work - CSCW '04 (p. 374). Chicago: ACM press. https://doi.org/10.1145 /1031607.1031669.

Zhang, Z., Zhou, L., Zhao, X., Wang, G., Su, Y., Metzger, M., et al. (2013). On the validity of geosocial mobility traces. In On the validity of geosocial mobility traces. In Proceedings of the Twelfth ACM Workshop on Hot Topics in Networks (HotNets-XII) (Vol. article 11, pp. 1-7). ACM. https://doi. org/10.1145/2535771.2535786.

Publisher's Note Springer Nature remains neutral with regard to jurisdictional claims in published maps and institutional affiliations.

\section{Affiliations}

\section{Marco Adelfio $^{1} \cdot$ Leticia Serrano-Estrada $^{2}$ • Pablo Martí-Ciriquián ${ }^{2}$ • Jaan-Henrik Kain ${ }^{1} \cdot$ Jenny Stenberg ${ }^{1}$}

1 Department of Architecture and Civil Engineering, Chalmers University of Technology, Gothenburg, Sweden

2 Building Sciences and Urbanism Department, University of Alicante, Alicante, Spain 